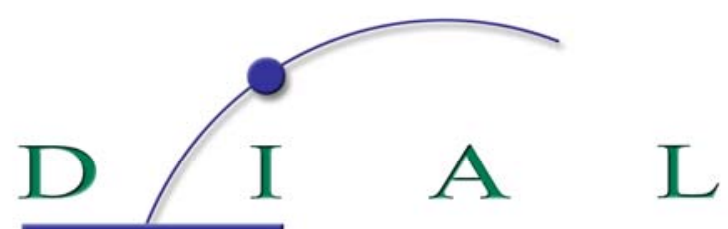

Développement Institutions \& Analyses de Long terme

DOCUMENT DE TRAVAIL

DT/2008-01

The Impact of European Settlement within French West Africa.

Did pre-colonial prosperous areas fall behind?

Elise HUILLERY 


\title{
THE IMPACT OF EUROPEAN SETTLEMENT WITHIN FRENCH WEST AFRICA DID PRE-COLONIAL PROSPEROUS AREAS FALL BEHIND? ${ }^{1}$
}

\author{
Elise Huillery \\ Paris School of Economics (PSE, DIAL - IRD \\ hmailto:huillery@dial.prd.fruillery@dial.prd.fr
}

Document de travail DIAL

Août 2008

\begin{abstract}
Did colonization change the distribution of prosperity within French-speaking West Africa? Using a new database on both pre-colonial and colonial contexts, this paper gives evidence that Europeans tended to settle in more prosperous pre-colonial areas and that the European settlement had a strong positive impact on current outcomes, even in an extractive colonial context, resulting in a positive relationship between pre and post-colonial performances. I argue that the African hostility towards colonial power to colonisation provides a random variation in European settlement since it damaged the profitability of colonial activities and dissuaded European from settling, but does not have a direct effect on current outcomes. Rich and hostile areas received less European settlers than they would have received had they not been so hostile, resulting in lower current performances partly due to lower colonial investments. Despite the absence of a "reversal of fortune" within former French West Africa, some of the most prosperous pre-colonial areas lost their advantage because of their hostility: other areas caught up and became the new leaders in the region.
\end{abstract}

Key Words : Colonization, Economic history, West Africa

JEL Code : N37, O11, P16

I am grateful to Denis Cogneau and Thomas Piketty for their valuable guidance. Alexander Moradi, José de Sousa and seminar participants at DIAL, Paris School of Economics, Nuffield College and the CSAE conference provided very helpful comments. Historical data used in this paper has been collected by Elise Huillery (the author) within the research project "Long Term History and Resources Distribution in Africa" directed by Denis Cogneau (IRD, DIAL, Paris). Financial support from the French Ministery of Research is gratefully acknowledged. Martine Lorenzo, Angélique Roblin, Xavier Midon and Angelina De Baecque have provided excellent research assistance for archive extraction. 


\section{Contents}

INTRODUCTION .................................................................................................................................. 5

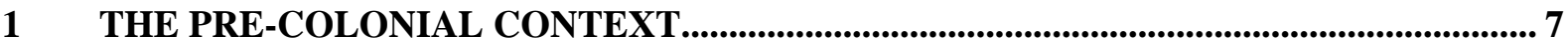

1.1 Pre-colonial economic prosperity …........................................................................................ 7

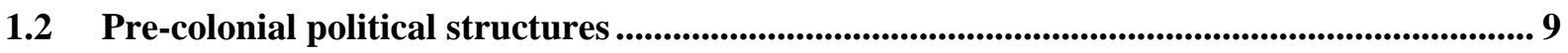

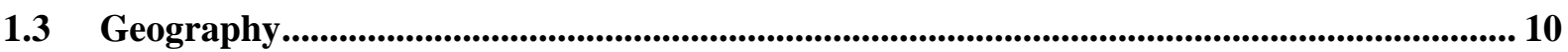

2 COLONIAL EXPERIENCE AND EUROPEAN SETTLEMENT …................................ 10

2.1 French political control on West Africa ...................................................................................... 10

2.2 The attractive effect of economic prosperity on European settlement .................................... 11

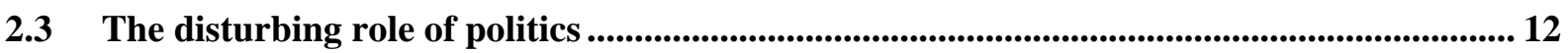

2.4 Evidence on the determinants of European settlement ........................................................... 14

3 THE IMPACT OF EUROPEAN SETTLEMENT ON CURRENT PERFORMANCES .. 15

3.1 Data on districts current performances .................................................................................... 15

3.2 OLS estimates of the impact of European settlement on current performances ................. 16

IV estimates of the impact of European settlement on current performances ...................... 16

4 WHY DID EUROPEAN SETTLEMENT PLAY A POSITIVE ROLE?............................... 19

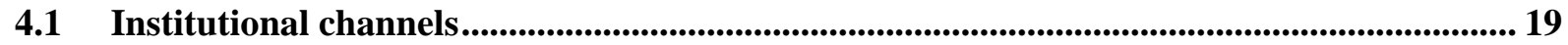

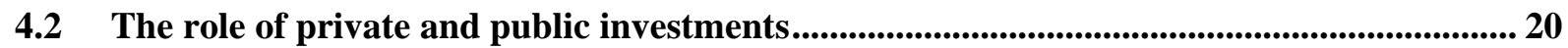

5 DID PROSPEROUS PRE-COLONIAL AREAS FALL BEHIND? .................................. 22

5.1 An overall change in distribution of prosperity? .......................................................................... 22

5.2 How much did hostile areas lose? ............................................................................................ 22

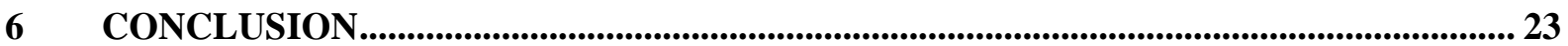

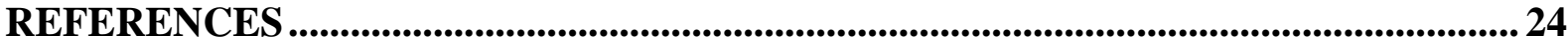

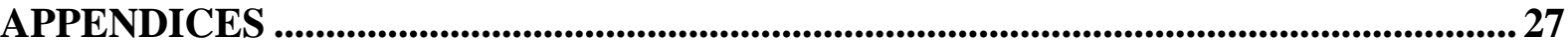

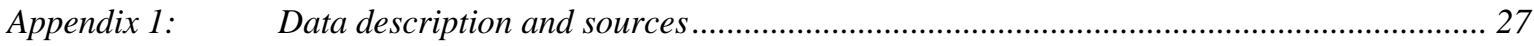

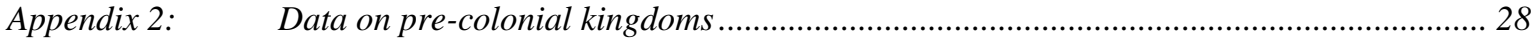

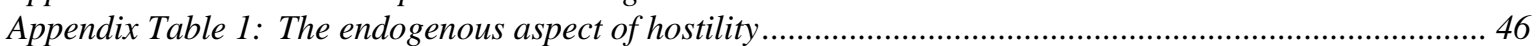

Appendix Table 2: Using distance from the nearest seaport as an alternative instrument........................... 47 


\section{List of tables}

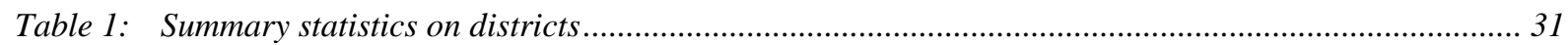

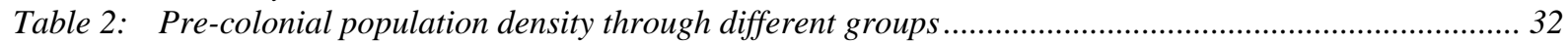

Table 3: The dissuasive impact of hostility and the attractive impact of pre-colonial economic

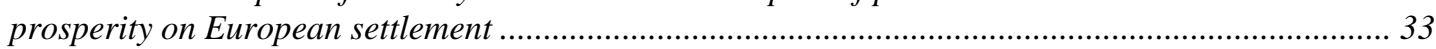

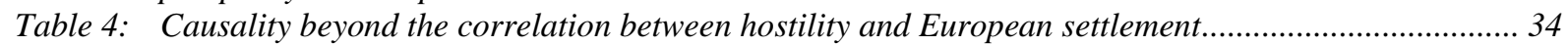

Table 5: The impact of European settlement on current outcomes: OLS and IV Estimates............................. 35

Table 6: Do colonial public investments explain the positive influence of European settlement? ..................... 36

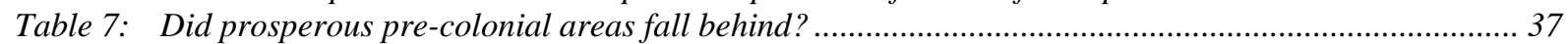

\section{List of Graphs}

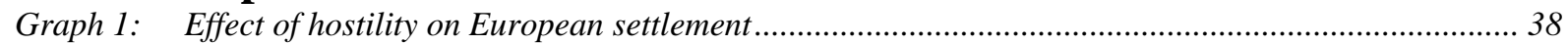

Graph 2: $\quad$ Settler mortality within former French West Africa ............................................................... 38

Graph 3: $\quad$ Consequences of hostility on European settlement 1925........................................................... 39

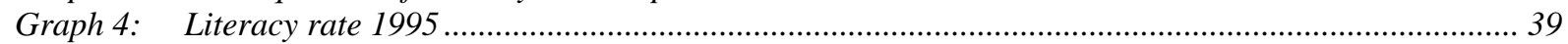

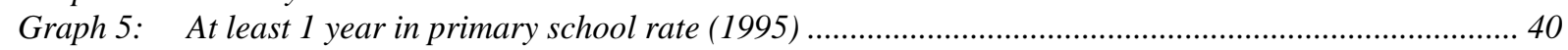

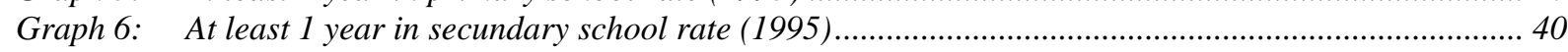

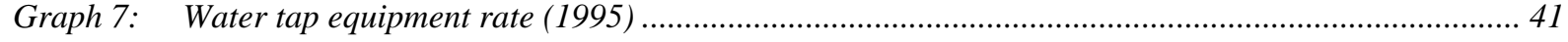

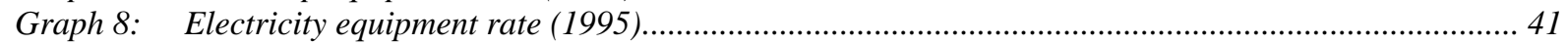

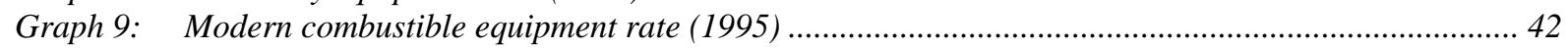

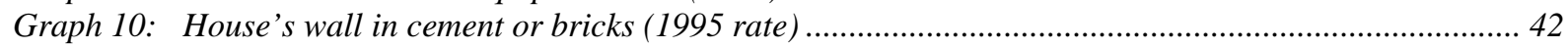

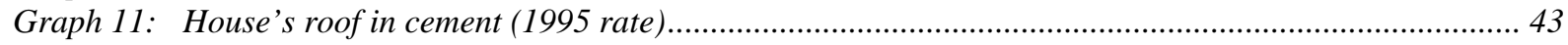

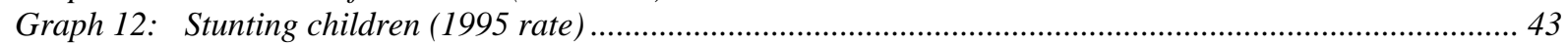

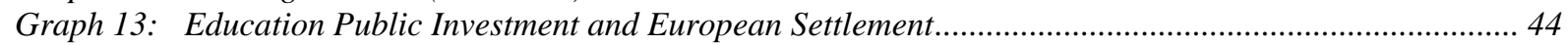

Graph 14: Health Public Investment and European Settlement .................................................................. 44

Graph 15: Infrastructure Investments and European Settlement................................................................ 45 


\section{INTRODUCTION}

At the worldwide level, the former colonies that were relatively rich in 1500 are now relatively poor. This evidence has been documented by Acemoglu, Johnson and Robinson (2002) who point out what they call a "reversal of fortune". They explain this reversal by two separate features: first, Europeans were more likely to settle in regions that were previously poor because poor regions were sparsely populated and this enabled Europeans to settle in large numbers. Second, the impact of European settlement on development path has been positive through the introduction of institutions encouraging investments (Acemoglu, Johnson and Robinson (2001)). In regions that were not suitable for heavy settlement, Europeans set up "extractive states" with little protection of private property and little checks and balances against government expropriation. At the other extreme, in regions where many Europeans settled, the settlers replicated European institutions with strong emphasis on private property and checks against government power. The positive impact of colonialism on current performances has been also recently documented by Feyrer and Sacerdote (2007). This paper finds a causal positive relationship between the number of years spent as a European colony and current GDP per capita among islands that were colonized during the Age of Discovery. They argue that this positive relationship runs through the quality of government and the raise in human capital. Both papers therefore underline the positive role of settlement: the more settlers during colonial times, the better economic performances today. Yet there is still a debate on where this result comes from. Acemoglu, Johnson and Robinson $(2001,2002)$ focus on the positive impact of heavy settlement on institutions whereas Feyrer and Sacerdote also recognize the potential additional role of settlers on human capital through the introduction of formal schooling and the direct importation of human capital since settlers themselves represent the embodiment of human capital.

Even if European settlement exhibits a positive impact on colonies on average, the question of whether this relationship remains positive among 'extractive colonies' - where colonizers pursued a strategy of resources extraction has not been examined. Following Acemoglu, Johnson and Robinson (2001, 2002), Europeans set up bad institutions in these colonies because relative prosperous areas made extractive institutions more profitable for the colonizers, for example to force the native population to work in mines or plantations and to limit the benefit of the rent to a small portion of the society. This lead to a specific organization of the society with poor incentives for investment, insecure property rights, bad administration of justice, etc. One may therefore expect the regions where more Europeans settled within extractive colonies to have suffered more than regions where few Europeans settled from the introduction of those bad institutions; under the institutional hypothesis, the impact of European settlement on current prosperity within extractive colonies should be negative. Or, if the effect of European settlement runs through mechanisms such as human capital, one may expect the regions where more Europeans settled within extractive colonies to overhang those where few Europeans settled. To answer this question, this paper therefore focuses on former French West Africa, a federation of "extractive" colonies dominated by France from 1895 to 1960. My central finding is that European settlement remains a positive determinant of current performances: colonized areas that received more European settlers have better performances than colonized areas that received less Europeans settlers. I strongly claim that these results do not mean that colonization per se was a good experience, since I do not compare colonized versus non colonized areas ${ }^{2}$. This result only means that, conditioned on being colonized, the more settlers the better, even among extractive colonies. Nor does this finding refute the "institutional hypothesis" since settlers actually brought bad institutions, resulting in a relative loss for the extractive colonies compared to the "Neo-Europes" and potentially an absolute loss for extractive colonies on the whole. However, this paper highlights the positive role of settlers on human and physical capital and shows that the negative impact of bad institutions could be locally balanced by the positive impact of capital investment.

It is worth noting that the positive impact of European settlement on current performances holds within colonial areas, but does not imply that colonization per se had a positive impact on development: it is likely that no colonization at all would have produced better current performances on the whole. 
This paper also investigates the question of the impact of colonization on the distribution of prosperity within former French West Africa. I document the fact that Europeans tended to settle in the most prosperous pre-colonial areas, which is consistent with the extractive policy pursued in the region. As a consequence, the general relationship between pre and post-colonial prosperity is positive. However, among West African areas that were relatively prosperous at the end of the nineteenth century, some are no longer more developed than the rest of the region today, for example the districts of Porto-Novo (Benin), Assinie (Ivory Coast), Dosso (Niger), Tivaouane and Casamance (Senegal), Mopti (Mali) or Bobo-Dioulasso (Upper Volta), among others. They lost their advantage while some poorer caught up with them: Cotonou, Abidjan, Niamey, Thies, Bamako, Ouagadougou... This paper shows that this reallocation of the leadership within former French West Africa is a consequence of the colonial experience. The reason is that some of the prosperous pre-colonial areas received less European settlers than others because they expressed more hostility towards colonial power in the early colonial times: refusal to apply colonial rules, to pay taxes, to enrol in forced labour and military recruits and to obey to administrators' commandments. As a result, the discriminated prosperous pre-colonial areas lost their relative advantage in the long run and other areas, less hostile towards colonial power, became the new leaders in the region.

From a methodological point of view, the first obvious difficulty in my empirical investigation is the lack of historical data. The paper uses a first-hand dataset that matches direct and precise historical data with current data at the district level. Colonial and pre-colonial data at the district level were collected by the author from historical archives in Paris and Dakar, whereas recent data come from (about) 1995 national household surveys. I matched both using the geographical coordinates of household locality and very precise maps of colonial districts. The second obvious issue is selection: why did Europeans settle intensely in certain areas? As Europeans were more likely to settle in economically more developed districts, the naïve estimates of the effect of European settlement on economic development might be upwardly biased. I pursue two strategies to better document the causal relationship between European settlement and current outcomes. First, I focus on a limited geographical area. To date, the macroeconomic literature on institutions and development has largely relied on cross-country regression evidence. Faced with the statistical challenge of isolating causal pathways, the use of cross-countries variables tends to derive instruments from persistent features of a country environment and limit their usefulness for studying institutional change (Pande and Udry, 2005). Following Banerjee \& Iyer (2005) and Iyer (2005), this paper uses variations between infranational districts, which gives an advantage with regard to the identification of European settlement influence: former French West Africa is much more homogeneous with respect to pre-colonial and colonial context than all former colonies, in particular with respect to geography, anthropology, precolonial history, the coloniser identity and the period and length of colonial times. The observed controls therefore capture a much larger part of the variation between districts than they use to do between countries all over the world. Second, I pursue an instrumentation strategy to better understand the causal relationship between European settlement and current performances. The instrument is the hostility towards colonial power as expressed in the early colonial period after conquest (1906-1920) by any act of protest like strikes, riots, or religious movements, refusal to obey from the local chiefs, difficulties in collecting taxes or in recruiting civil servants or refusal to do coerced labour. These manifestations of hostility were likely to amputate most of the profitability of colonial activities. One issue is that hostility may proxy heterogeneity across districts directly correlated with current outcomes. As evidence shows, hostility actually tended to be higher in more prosperous and more socially and politically cohesive areas. But the evidence from African historians on hostile areas strongly supports the fact that hostility was also largely accidental. Conditionally to observable characteristics that capture most of the endogenous part of hostility, I therefore argue that hostility is a good instrument for European settlement. Furthermore, one may be reassured on the validity of my basic results by the fact that this strategy is likely to produce downwardly biased estimates of the effect of European settlement on current performances since there is clear evidence that the areas that tended to select into hostility towards colonial power were the most able to advance economically to modern age. 
This paper therefore shows first that European settlers preferred prosperous areas in West Africa, which is consistent with the extractive policy pursued in the region. European colonization thus tended to reinforce pre-colonial inequalities by settling in prosperous areas. Second, this preference towards prosperous areas was sometimes discouraged by hostility towards colonial power. Hostility actually dissuaded Europeans from settling. When hostility was really severe in a prosperous area, Europeans preferred to settle in a calm neighbor area even if it was less prosperous. Third, European settlement had a positive and persistent influence on current performances. Differences in hostility towards colonial power thus explain why some changes in the prosperity distribution occurred within former French West Africa. But the final result is that the distribution of prosperity within former French West Africa did not reverse. Changes affected only hostile areas and these areas did not become the poorest in the region, even if other areas caught up with them and sometimes overhung. With respect to the existing literature, this paper innovates in four ways. First, it highlights the role of the African attitude towards colonialism in colonization features. Second, the paper extends the positive role of European settlement within an "extractive strategy" area. Third, it disentangles between two main channels of the positive role of European settlement, institutions and (human and physical) capital. Fourth, the paper documents the evolution of prosperity distribution within former French West Africa since 1900 .

The paper is structured as follows. Section 1 provides a description of the pre-colonial context. Sections 2 analyses the determinants of European settlement during colonial times. Section 3 measures the impact of European settlement on current performances. Section 4 explores some explanations of the positive impact of European settlement on current performances. Section 5 documents the change in prosperity distribution within former French West Africa. Section 6 concludes.

\section{THE PRE-COLONIAL CONTEXT}

Information on the pre-colonial context is crucial to examine the evolution of prosperity distribution since 1900. I will particularly focus on economic prosperity, but political and geographical factors are also helpful to capture the different aspects of the pre-colonial context. The main issue is the lack of data for such early times, which is far more problematic at the district level than at the national level. This section therefore review evidence from African historians and describes the data used to capture pre-colonial district differences. All data are original ones.

\subsection{Pre-colonial economic prosperity}

At the end of the nineteenth century, French West Africa was a vast territory of $4800000 \mathrm{~km}^{2}$ populated by a scarce population of around 12000000 people $^{3}$. Population density was therefore very low (2.5 people per $\left.\mathrm{km}^{2}\right)$. West Africa was mostly a rural area. Towns were scarce and small: colonial censuses $^{4}$ in the 1900s report that the five biggest towns were Saint-Louis (about 24000 habitants), Dakar (18 400), Rufisque (12 500), Conakry (8 200) and Cotonou (4 400). Most people in West Africa were thus farmers. As documented in Curtin (1978), fishing along the coast and rivers was an intensive and specialized occupation. Dry-season hunting was a major source of meat in savanna and forest alike. People mined rock salt in the Sahara and evaporated sea salt along the coast. Iron was found almost everywhere in West Africa, but some regions with the best ore became iron centres and sold their iron to other regions less well endowed. Still other regions concentrated on cotton and cotton textiles or on sheep breeding and woollen cloth.

As a result, regular patterns of internal trade helped to exchange the surplus of one region with others. The vegetation zones stretching east and west encouraged extensive north-south trade. Trade in turn

I calculated the French West African population about 1910 using the censuses made by French districts' administrators between 1906 and 1912. These censuses are available at the Archives Nationales, Paris, Fonds Afrique Occidentale Française, série G, sous-série 22.

$4 \quad$ Paris, Archives Nationales, Fonds Afrique Occidentale Française, série G, sous-série 22. 
encouraged the growth of small towns, some near the desert-edge to profit from trans-Saharan trade, like Tombouktou, Agadez, Gao and Oualata, others well back from the desert, like Jenne, BoboDioulasso, Kankan and Borgou, located to profit from the transit along commercial routes between the savanna and the forest. Curtin (1995, p.325) writes that in the nineteenth century "internal trade was still far more important than trade with the world overseas, as it had been in the period of slave trade". For most of sub-Saharan Africa, overseas trade was only a small fraction of total trade. Curtin reports that the nineteenth-century kola nut trade from Asante to the savanna country increased even more in value than did the palm oil exports from the Gold Coast. Islam was the religion of commerce and it was strong in ethnic groups with commercial calling like Juula.

Regarding overseas trade however, coastal West Africa, as Central Africa, had a longer and more intense experience of maritime trade than any other part of sub-Saharan Africa. Legitimate trade had replaced the slave trade in importance at the end of the nineteenth century. But the new exports came from particular regions that "were not the same regions that had profited from the slave trade" (Curtin (1995, p.326)). He continues: "With the winding down of the trade in slaves, the new "legitimate" trade was not merely a substitution of the old; it shifted the centres of wealth and power. Those who had benefit from slave trade lost out, and new wealth to those who could supply gum-Senegal, palmoil or peanuts". An important difference with slave trade was also that the payoff for the non-slave trade went in part to merchants, but also to producers who took a share.

The question is how to measure these pre-colonial economic patterns. The main variable that I use to capture economic prosperity is the density of population. As documented by Malthus (1798) and Bairoch (1988), only prosperous areas could support high population densities. From a Malthusian point of view, more natural resources and agrarian prosperity is necessary to maintain a higher population density. This measure is therefore more appropriate in the case of rural societies like precolonial West Africa than in modern industrialised societies where the agricultural factor is no longer so much crucial. I thus collected data on local population from colonial censuses and land area from colonial maps at the district level and calculate population density by dividing total population by land $\operatorname{area}^{5}$. The earliest measure I can use is the population density in 1910, a few years after the beginning of the effective French colonial occupation. Map 1 reports the distribution of population density in 1910. The most densely populated areas were the South of current Benin, the Mossi land in current Upper-Volta, the Wolof region in the Western part of current Senegal and the Fuuta Jaalo in CentralWest Guinea.

But population density does not capture the relative prosperity of southern Saharan belt areas because these areas are located at the desert-edge so they are arid and sparsely populated, but during the nineteenth century they profited from a dynamic trans-Saharan trade and were well-known to be relatively prosperous. It was under Mali that the great cities of the Niger bend prospered, with Gao, Jenne and Timbuktu in particular becoming known across Europe for its great wealth. Important trading centers in southern West Africa developed at the transitional zone between the forest and the savanna like Bondoukou (in present-day Ivory Coast). Western trade routes continued to be important, with Ouadane, Oualata and Chinguetti being the major trade centres in what is now Mauritania, while the Tuareg towns of Assodé and later Agadez grew around a more easterly route in what is now Niger ${ }^{6}$. The population density is thus not sufficient to capture differences in prosperity within West Africa. I therefore include a dummy for desert-edge areas in my econometric framework in order to take into account this specificity as regard to population density.

It is more usual to divide total population by arable area but there are two reasons why I do not use arable area: i) a methodological reason which is that some districts are completely in the desert so their arable land is zero and ii) a pragmatic reason which is that except for the desert-edge districts arable land and total land are equal: our measure of land area excludes inland water and FAO data shows that the total rest of the land is arable (the map is available on http://www.fao.org/farmingsystems/FarmingMaps/SSA/12/AL/map/m10000.html). Using total land or arable land therefore does not change anything except for the desert-edge areas.

These information come from a comprehensive and detailed article on the trans-Saharan trade written by the historian Pekka Masonen which can be read at: http://www.hf-fak.uib.no/institutter/smi/paj/Masonen.html 
Finally, even if the relative importance of overseas trade with respect to internal trade was not so important at the regional level, exports toward European countries accelerated the pace of economic development especially in the coastal trade counters. Since the trade counters concentrated many economic activities, many African people and also attracted many Europeans, they are to be considered as specific in my empirical framework. I will therefore include a dummy for the presence of a European trade counters in the district to capture this particular feature of the distribution of economic prosperity within what will become French West Africa.

\subsection{Pre-colonial political structures}

The West African political context changed before the colonial period because of what Curtin calls a "religious revolution". Revolutionaries who claimed a religious motive had been important since the seventeenth century from the middle Senegal to the highlands of Fuuta Jaalo. Before, Islam had been gaining gradually throughout Western Sudan, but its gains had come as pockets of adherents, not a broad expansion across the countryside. From 1780 to 1880, preachers and moral leaders often called for jihad resulting in a substitution of new rulers for old and new large states for the former small states, and a substantial spread of Islam as a religion (Sellier (2003)). Many West African states are therefore officially related to Islam.

Pre-colonial political structures were obviously various but they can be reasonably classified in three categories. At one extreme, full-time rulers claimed authority over every individual within a define territory. These were clearly states, also called kingdoms or empires. At the other, authority was so dispersed that no rulers could be identified. Stateless societies could work in many different ways, but the key building block was usually the lineage. That is why African anthropologists often call them "lineage-based societies". They are also called "decentralized societies", "segmentary societies" or "autonomous local systems" (Murdock (1967), Barrett (1968), Mitchell and Paden (1989), Morrison (1989)). State and stateless societies have existed side by side over nearly two millennia "without stateless people feeling a need to copy the institutions of their more organized neighbours" (Curtin (1995)). Between these two extremes cases, those African anthropologists identify a third category which corresponds to chiefdoms and city-states, which were smaller political units than the kingdoms. They also claim that political structure should not be assimilated with the size of society: some African states were very small and some stateless societies were very large.

In this paper, I follow African anthropologists or economists which already worked on this topic (Morrison, Mitchell and Paden (1989), Murdock (1967), Barrett (1968), Englebert (2000)) and distinguish three pre-colonial political statuses: kingdoms or empires, chiefdoms and completely amorphous areas. Yet I do not use the index of state-like nature of pre-colonial systems used in Englebert (2000) because this index is at the national level. As I need more precise information at the district level, I use evidence from African historians (Boahen (1989), Bouche (1991), CoqueryVidrovitch \& Moniot (1993), Ki-Zerbo (1978)). There is a strong consensus from these historian sources on the location of pre-colonial kingdoms, chiefdoms and amorphous areas so it was not so difficult to construct a dummy for each of these three categories. Completely amorphous areas correspond to a total absence of political authority, also called "lineage-based societies" in Englebert (2000) or "segmentary systems" in Murdock (1967). These amorphous areas were located in forest Guinea (Toma and Guerze), in South-Western Ivorian forest (Krou), in Casamance at the South-West of Senegal and in Atakora at the North-West of Benin (Somba). Kingdoms correspond to large areas with political control concentrated in the hands of a few people, with an ability to collect revenue and tribute, usually through the control of trade, and to control an army to defend. Appendix 1 shows the corresponding districts, the name of the related pre-colonial kingdom and the historian sources that allow me to construct these data. Approximately half of the colonial districts were parts of pre-colonial kingdoms and 13 colonial districts were parts of completely amorphous pre-colonial areas. Table 2 shows that pre-colonial well-structured kingdoms had significantly higher population densities than the rest of the region. In other words, political development and economic prosperity were positively correlated, which is consistent with Stevenson's view of higher population densities in traditional 
states in sub-Saharan Africa and lower ones in the non-states regions (Stevenson (1968)). This can be explained because stateless societies had several problems: warfare for a large scale called for military command and permanent officials, traders needed a way to protect goods for transit, a system of law allowing aliens to come and go in peace, make it easy to borrow and to collect debts. This could be offered only by permanent officials and central direction. A reverse causation is also plausible: densely populated areas were likely to coincide with a higher division of labour which probably requires a higher level of political organization than extensive labour organization.

\subsection{Geography}

West Africa is like a peninsula attached to the mass of sub-Saharan Africa at the Cameroon mountains and stretching westward between the gulf of Guinea and the Sahara. It is one those longitudinal layers of climate and vegetation zones with orderly progression from north to south. Beginning with the Sahara, the sequence is desert, savanna, forest. Geographers discriminate carefully between the vegetation and climatic subdivisions within each of these zones. Tropical rain forest can be imagined as steaming jungle, and some of it is, but people can change that, and the forest zone today supports some of the densest agricultural populations in Africa as has done for centuries. A physical explanation for differing natural vegetation is the difference in annual rainfall. Differences in climate can therefore be captured by differences in latitude, longitude and rainfalls. In West Africa, it varies from 160 inches at a few places along the coast to less than fifteen inches at the edge of the desert. Crops that need more rain or longer growing season can only be grown further south.

Another factor explaining differences in natural circumstances is rivers. Certain north-flowing rivers like the Senegal and the Upper Niger provide a kind of safety valve. These rivers overflow their banks and carry both silt and moisture to the surrounding fields. Crops are planted on the wet fields as the water recedes and grow during the early dry season. I therefore constructed a dummy for the presence of navigable river. Since altitude is also an important determinant of disease environment, I include for each district the altitude of its main town. Finally, access to sea is a strong determinant of economic potentialities (exports, salt production, fishing along the coast). I therefore include a dummy for coastal districts. Please refer to Appendix 1 for more detail on data sources.

\section{COLONIAL EXPERIENCE AND EUROPEAN SETTLEMENT}

\subsection{French political control on West Africa}

The decade of the 1880s was a major turning point in African history. It brought most of the continent rapidly and brutally into the colonial period. But the colonial conquest was far more slow-acting than usually presented: military expansion began actually in 1854 and almost achieved at the beginning of the twentieth century only. Moreover, military pacification was still active until 1929, especially in desert-edge areas but not only. The French military push began in 1854 from the Senegalese coasts to the upper Senegal, driven by the famous General Faidherbe. A first military column went from the Senegalese coasts eastbound and arrived in the late 1850s at the west side of current Mali (Kayes, Satadougou). A second military expansion was engaged during the 1850 s northbound to current Mauritania. A third military expansion took place along the Guinean coasts (Conakry, Boffa, Boke, Forecariah). South Dahomey was then the only new expansion of the 1860s. No new expansion occurred during the 1870s. Until 1880, colonial military push was thus limited to coastal incursions. The process amplified in the 1880s with a west-to-east progress from Senegal to the northern Gold Coast, joined by south-to-north incursions from coastal posts in Ivory Coast. In the 1890s, a last military column progressed west-to-east from the south-east side of current Mali as far as Lake Tchad, joined by a column progressing south-to-north from Dahomey.

Paper annexation, however, was only the framework for French West colonial Africa. The reality drew far more heavily on the actual process of conquest. French West Africa was officially created in 1895 
and abolished in 1960. Despite a military control on the major part of the territory around 1900, there were no sensitive all-day life modifications for local people before 1900-1910 except in few coastal localities. Local chiefs' prerogatives in particular were in general still intact, their military obedience being materialised by friendship treaties only. Yet hostile chiefs suffered from French military repression: French military forces defeated and killed Lat Joor of Kajoor in 1886, pursued Mamadu Lamin to his death in 1887, exiled Samori Ture to Gabon in 1898 where he died two years later, among others (Ki-Zerbo (1972)). The physical occupation of the whole territory was thus not yet effective when French West Africa was officially created. French West Africa was a federation of colonies and a federal government was created in 1904. Colonial administrative reports give evidence that the effective direct administration of the large and populous territories began in the first decade of the twentieth century, as civil administrators progressively replaced military forces. The colonial occupation has therefore been effective in the major part of the territory from approximately 1910 to 1960.

\subsection{The attractive effect of economic prosperity on European settlement}

District-level data on European settlers comes from colonial censuses and was collected on my own. The number of European settlers was globally very low as in almost all extractive colonies in Africa, India and Asia (Mc Evedy \& Jones (1975), Curtin (1995, p. 435)). The African colonies where the proportion of Europeans exceeded 1\% are Southern and South-Central Africa, Angola and the Maghreb (Acemoglu, Johnson and Robinson (2001)). In 1910, there was a total of 7,610 Europeans living in French West Africa, which progressively increased to 13,239 in 1925 and 53,087 in $1950^{7}$. Europeans represented 0.6\% of French West African population in 1910, 1\%o in 1925 and 3\%o in 1950. At the district level, which is my statistical unit in this paper, the average number of European settlers grew up from 68 in 1910 to 118 in 1925 and 525 in 1950. But these figures mask a huge heterogeneity across districts which can be appreciated by the gap between the average number of European settlers per district and the median one: half of the districts had less than 16 settlers in 1910, 23 in 1925 and 86 in 1950. They represented on average 2\%o of districts population in 1910, 3\%o in 1925 and $4 \%$ in 1950.

What explains differences in European settlement? From a theoretical point of view, we could expect Europeans to prefer pre-colonial prosperous areas. The colonial strategy was actually extraction. Profitability of extraction was likely to be higher in prosperous areas because dense population provided a supply of labour that could be forced to work in plantations and public works (Acemoglu, Johnson and Robinson (2002)). Moreover, extractive strategy was also more profitable in prosperous areas because there were simply more resources to be extracted (Acemoglu, Johnson and Robinson (2002)). Curtin (1995, p. 447) writes that "European capital was invested where exploitable resources promised the most extractive returns". Agriculture was the main activity for most of West Africa, and economic development meant agricultural development, which implied new crops and new techniques to increase total yields. Planners were likely to pursue policies to increase yields that could be channelled into exports: take land from the Africans, bring in European managers, and set up plantations using African labor (Curtin 1995, p. 450). Export crops like peanuts or cocoa have developed rapidly since the end of the nineteenth century. Infrastructures had to be built to move crops to the river ports or to the coast. All these economic patterns demanded labour and resource endowments. In spite of directed development schemes, African farmers did most of the work. Europeans were therefore expected to settle in densely populated areas as well as in trading posts for export activities. The situation of Equatorial Africa was a bit different because Europeans developed mining activities in areas that could be sparsely developed, depending on mining resources discovery. But colonial extraction in West Africa focused on agriculture (there was only very little mining extraction on the French part of West Africa) and was therefore likely to take place in pre-colonial densely populated areas.

Actually this is not the exact number of Europeans in 1950 since I used censuses from 1947 to 1953 to compute this figure, depending on data availability at the colony level. 


\subsection{The disturbing role of politics}

The relationship between political pre-colonial organisation and European settlement could potentially be both positive and negative. On the one hand, well-structured societies could have attracted European settlers by providing them an existing system of tax, an administration, and also a tribute to rely on. Following the results of Nicola Gennaioli \& Ilia Rainer (2007), the profitability of European investments could be higher in state rather than in stateless societies by increasing the accountability of local chiefs. The problem with stateless societies was actually that they had no one in authority to discipline local population, whereas in state societies collaboration of local chiefs could accelerate the implementation of colonial rule. Resistance could also be high in stateless societies: they have no one in authority capable of surrendering for the entire group. The French had actually to force the surrender of each individual kinship segment. But on the other hand, existing African authorities in politically well-organized societies were more likely to interfere with colonial extraction. The number of European administrators was very small in relation to the huge African territories they governed. Despite European military superiority, Africans were however capable to resist, especially in socially coherent and well-organized societies. Curtin (1995, p. 514) says that "(primary resistance) was usually organized by the pre-colonial states". Acts of protest, like strikes, riots or religious movements were likely to be stronger in societies that have good properties for "collective action", broadly political, cultural, ethnic or religious homogeneity. Curtin (1995, p. 515) writes for instance that "a common religion was one source of unity (...) colonial officials therefore paid careful attention to Islam as a potentially unifying force". In conclusion, well-structured societies could have presented some advantages for colonial authority potentially compensated by some disadvantages, depending of their relative degree of resistance and obedience to colonial rules. African hostility towards colonial power could thus have been an important determinant of the profitability of colonial extraction and therefore of European settlement.

To test this empirically, I collected data on the African attitude towards French power and especially hostility at the district level. Data come from the political annual reports ${ }^{8}$ written by the districts administrators to the Governor. These reports aimed to inform the Governor on the political climate in each district of the colony. The districts administrators therefore told every political event that occurred in their district during the year: good or bad spirit of the population, riots, opposition from the local chiefs, difficulties in collecting taxes or in recruiting civil servants, refuse to do coerced labour etc. I9 read every report for years ending by "3", "6" and "9" from 1906 to 1956, and coded political events expressing hostility towards colonial power. These events could involve different actors: local chiefs, isolated individuals, small groups, major groups or the whole district population. They could also be of different degrees of importance. First, I classified an expression of hostility as of minor importance when it did not put the colonial authority under threat, for example when the administrator judged a local chief as "apathetic", "dormant" or "ignorant" - which in general meant that the chief was not very enthusiastic to collaborate with the colonial administration - or when there was a clash between an isolated individual and the colonial power if the attitude of this individual does not reflect the general spirit of any group of people in the district. Second, I classified an expression of hostility as of moderate importance when it clearly showed the determination to jeopardize the colonial power but did not necessitate any violent intervention from the French administration: for example a clash with a significant group in the district without military repression, people running away to escape tax collection or the activism of religious movements. Third, I classified an expression of hostility as of severe importance when it clearly showed the determination to jeopardize the colonial power and necessitated a violent intervention from the French administration: for example a military repression of a riot, the destitution of a local chief, the dispatching of policemen to force people to pay taxes or enrol in coerced labour, or the intervention of justice to punish some rebellious people.

Paris, National Archives, Fonds Afrique Occidentale Française, série G, sous-série 2

Angélique Roblin also provided excellent assistance for these data collection. 
To construct a relevant measure of hostility, I focus on the period 1906-1920. What interests me is actually the hostility that might dissuade Europeans from settling. Before 1906, there were no political reports because there was no effective direct administration of the large and populous territories, as explained above (p.11). I thus do not take into account what historian call the "primary resistance", which was the initial military resistance to the colonial conquest. This period of military conquest was actually a "diplomatic" period of paper annexation and friendship treaties. Almost only militaries were present in French West Africa, and only for conquest purpose. The arrival of European settlers began at the end of the military pacification, contemporaneously with the implantation of an administrative structure. After 1920, the expressions of hostility declined and were not so determining for settlers who were influenced by the location of their predecessors. As I show in Huillery (2007), there was an important path-dependent feature in the colonial era and the early colonial times were particularly crucial for the later ones. After 1945 French administrators faced to a new kind of hostility called "modern nationalism" by historians, which was borrowed from the West by the local western-educated elite with the goal of taking over the colonial state after World War II. This new resistance does not really much matter for this paper because it took place mostly in capitals and favoured areas at the end of colonial era (1945-1960) and did not influenced the primary location of European settlers. What interests me is thus the "third type of African resistance" (Curtin (1995, p. 514), Rioux (2007, p. 668)): the resistance through refusal to obey, to pay taxes, to do coerced labour and to enrol in police forces, which affected directly the profitability of colonial activities and was likely to influence European settlement at the beginning of colonial period.

I use three indicators of hostility: the first indicator (H1) equals to the occurrence rate of events expressing hostility over 1906-1920, that is the number of years for which at least one event expressing hostility was reported in the political annual report as a percentage of the total number of observations over 1906-1920. The second indicator (H2) equals to the occurrence rate of only severe events expressing hostility. The third indicator (H3) equals to the average annual number of severe events expressing hostility. The difference between $\mathrm{H} 1$ and the two others is that the two others focus on severe events only. $\mathrm{H} 2$ and $\mathrm{H} 3$ are thus less dependent from the variations in the narrative profusion of districts administrators and they discriminate between lightly and severely hostile areas. The difference between $\mathrm{H} 2$ and $\mathrm{H} 3$ is that $\mathrm{H} 3$ discriminate areas according to the annual number of events expressing hostility. Hostility could actually express only once a year but also twice or more. $\mathrm{H} 3$ thus takes into account another dimension of severity which is the number of expressions.

To make this completely clear, let me give an example. Take three districts $\mathrm{A}, \mathrm{B}$ and $\mathrm{C}$ and two years $\mathrm{T}$ and $\mathrm{T}+1$. The following table reports the number of events expressing hostility regarding their degree of importance and the resulting values of $\mathrm{H} 1, \mathrm{H} 2$ and $\mathrm{H} 3$ over $(\mathrm{T}, \mathrm{T}+1)$.

\section{Measures of hostility: Examples}

\begin{tabular}{|c|c|c|c|c|}
\hline & & A & B & C \\
\hline \multirow{3}{*}{$\mathrm{T}$} & Minor & 1 & 0 & 0 \\
\cline { 2 - 5 } & Moderate & 0 & 1 & 2 \\
\cline { 2 - 5 } & Severe & 0 & 1 & 0 \\
\hline \multirow{3}{*}{$\mathrm{T}+1$} & Minor & 1 & 1 & 0 \\
\cline { 2 - 5 } & Moderate & 0 & 0 & 2 \\
\cline { 2 - 5 } & Severe & 0 & 1 & 1 \\
\hline \multicolumn{2}{|c|}{1} & 0.5 & 2 \\
\hline
\end{tabular}

The correlations between these three indicators are very large, 0.80 between $\mathrm{H} 1$ and H3, 0.92 between $\mathrm{H} 1$ and $\mathrm{H} 2$, and 0.87 between $\mathrm{H} 2$ and $\mathrm{H} 3$. The obtained thereafter results do actually not depend on which indicator is used. Table 1 shows that hostility was a major issue according to the annual political reports: on average, the occurrence rate of events expressing hostility (H1) is 0.49 , what means that on average districts experienced hostility every two years. The vast majority of these events was severe since the occurrence rate of severe events $(\mathrm{H} 2)$ is 0.43 . Finally, taking into account 
the number of hostility expressions within a year (H3), districts experienced on average 1.03 severe events per year. The variations are large since some districts experienced no hostility at all whereas others experienced hostility every year with on average more than 4 severe events per year. Map 3 shows the distribution of hostility within former French West Africa. Districts administrators assigned an important part of their reports to problems related to hostility since consequences for the all-day life and management of the districts were sensitive: bad spirit of the population, riots or opposition from the local chiefs prevented administrators to implement colonial rules and projects. The participation of local people was necessary for many colonial public or private activities like plantations or public works. Moreover, difficulties in collecting taxes or in recruiting civil servants directly affected the material resources of the colonial administration. Hostility was therefore a crucial issue for the colonial power.

\subsection{Evidence on the determinants of European settlement}

I test empirically this expected correlation between European settlement, pre-colonial economic prosperity and hostility by running ordinary least squares regressions of the form:

$$
\mathrm{E}_{\mathrm{i}}=\alpha+\delta \mathrm{H}_{\mathrm{i}}+\mathrm{P}_{\mathrm{i}} \gamma+\mathrm{S}_{\mathrm{i}} \mu+\mathrm{X}_{\mathrm{i}} \lambda+\varepsilon_{\mathrm{i}}
$$

where $E_{\mathrm{i}}$ is the share of Europeans in district $i$ population in $1925, \mathrm{H}_{\mathrm{i}}$ is the measure of hostility in district $i$ over 1906-1920, $\mathrm{P}_{\mathrm{i}}$ a set of proxies for pre-colonial economic prosperity in district $i, \mathrm{~S}_{\mathrm{i}}$ a set of proxies for pre-colonial political status of district $i$ and $X_{\mathrm{i}}$ a set of geographical controls variables. My coefficients of interest are $\delta$ and $\gamma . \delta$ represents the dissuasive effect of hostility on European settlement and $\gamma$ the direct effect of pre-colonial economic prosperity net of its correlation with hostility. Note that Dakar and Saint-Louis are excluded from the sample because of the lack of data on political climate in these two specific districts ${ }^{10}$.

Table 3, panel A shows that the dissuasive impact of hostility was large and significant: One additional severe event expressing hostility per year reduced the number of European per 1000 inhabitants in 1925 by one. The size of this effect is important since the number of Europeans per 1000 inhabitants in 1925 was $2.7^{11}$. One severe event expressing hostility per year equals exactly the mean and the standard deviation of $\mathrm{H} 3$.

In order to precise the negative influence of hostility, I also examine whether hostility discriminated more rich areas than poor areas. The effect of hostility could actually be different along the distribution of pre-colonial prosperity. To test such a difference, I include the interaction term between hostility and economic prosperity in the regression:

$$
\mathrm{E}_{\mathrm{i}}=\alpha+\delta \mathrm{H}_{\mathrm{i}}+\mathrm{P}_{\mathrm{i}} \gamma+\mathrm{H}_{\mathrm{i}} * \mathrm{P}_{\mathrm{i}} \nu+\mathrm{S}_{\mathrm{i}} \mu+\mathrm{X}_{\mathrm{i}} \lambda+\varepsilon_{\mathrm{i}}
$$

where $\mathrm{E}_{\mathrm{i}}$ is the share of Europeans in district $i$ population in $1925, \mathrm{H}_{\mathrm{i}}$ is the measure of hostility in district $i$ over 1906-1920, $\mathrm{P}_{\mathrm{i}}$ a set of proxies for pre-colonial economic prosperity in district $i, \mathrm{H}_{\mathrm{i}} * \mathrm{P}_{\mathrm{i}}$ is the product of hostility with proxies for pre-colonial economic prosperity, $\mathrm{S}_{\mathrm{i}}$ a set of proxies for precolonial political status of district $i$ and $\mathrm{X}_{\mathrm{i}}$ a set of geographical controls variables. My coefficients of interest are now $\delta, \gamma$ and $v$. $\delta$ represents the overall dissuasive effect of hostility, $\gamma$ represents the overall effect of pre-colonial economic prosperity and represents the supplemental effect of hostility depending on economic prosperity.

Table 3, panel B shows that the dissuasive effect of hostility was larger for densely populated areas than for sparsely populated areas, larger for desert-edge areas than other areas and larger for trade counters than other areas. Graph 1 represents the differences in the dissuasive impact of hostility along

\footnotetext{
10 Dakar was the capital of the French West Africa and Saint-Louis the capital of Senegal and Mauritania. These two cities had a particular legal status. Consequently, no annual political reports were written on Dakar and Saint-Louis. The number of observations is thus 110

11 Remember that this statistic is calculated without Dakar and Saint-Louis.
} 
the distribution of the population density. It shows that the most hostile areas at the $75^{\text {th }}$ percentile of population density lost 2 European settlers per 1,000 inhabitants, whereas the most hostile areas at the $25^{\text {th }}$ percentile of population density lost only 0.5 European settlers per 1,000 inhabitants. Controlling for this ascending dissuasive effect of hostility on European settlement, the positive influence of precolonial economic prosperity is large and significant. These results thus confirm the previous predictions: (i) Europeans were more attracted by prosperous areas but (ii) hostility disturbed this preference and created large differences in settlement within prosperous areas.

One can have concern that the negative relationship between European settlement and hostility towards colonial power could reflect a reverse causation. I actually interpret this negative correlation as a negative impact of hostility on European settlement, but we could also interpret this correlation as a negative impact of European settlement on hostility: the more Europeans in the districts, the less hostile. This issue has to be considered. To address this reverse causation issue, I use a Granger causality type argument thanks to the evolution patterns of European settlement and hostility. I have three measures of European settlement in 1910, 1925 and 1950, which $I$ call $E_{1}, E_{2}$ and $E_{3}$. I also have three indicators of hostility over 1906-1920, 1920-1940 and 1940-1960 which $\mathrm{I}$ call $\mathrm{H}_{1}, \mathrm{H}_{2}$ and $\mathrm{H}_{3}$. If the negative coefficient $\delta$ in equation (3) was driven by a negative impact of European settlement on hostility, a higher $\mathrm{E}_{1}$ would produce a lower $\mathrm{H}_{2}$ and a higher $\mathrm{H}_{1}$ would not necessarily produce a lower $E_{2}$. This can be tested by running regressions of the form:

$$
\mathrm{E}_{\mathrm{t}, \mathrm{i}}=\alpha+\delta \mathrm{H}_{\mathrm{t}-1, \mathrm{i}}+\beta \mathrm{E}_{\mathrm{t}-1, \mathrm{i}}+\varepsilon_{\mathrm{i}}
$$

Where $\mathrm{E}_{\mathrm{t}, \mathrm{i}}$ is the number of Europeans per 1,000 inhabitants in time $t$ in district $i, \mathrm{H}_{\mathrm{t}-1, \mathrm{i}}$ is the level of hostility in time $t-1$ in district $i$ and $\mathrm{E}_{\mathrm{t}-1, \mathrm{i}}$ is the number of Europeans per 1,000 inhabitants in time $t-1$ in district $i$. With this specification, the coefficient $\delta$ represents the causal impact of hostility on European settlement since the potential effect of European settlement on hostility is captured by $\mathrm{E}_{\mathrm{t}-1, \mathrm{i}}$.

Results are reported in table 4. Hostility towards colonial power clearly had a negative causal impact on European settlement (note however that the coefficient is not significantly different from zero in panel $C$ ).

\section{THE IMPACT OF EUROPEAN SETTLEMENT ON CURRENT PERFORMANCES}

\subsection{Data on districts current performances}

Data on current performances come from national household survey in Senegal, Benin, Mali, Niger, Guinea, Mauritania, Upper Volta and Ivory Coast ${ }^{12}$. The total number of districts is 112 but I exclude Dakar and Saint-Louis from the sample since there is no data on political climate in these two particular districts. I collected the geographical coordinates of household localities and matched localities with their colonial district using these coordinates and 1925 colonial maps. This enabled me to compute statistics on districts current performances ${ }^{13}$.

The use of different national household surveys limited the number of common variables that can be used. I choose to focus on indicators of permanent income rather than on income or consumption because of their higher volatility. The idea is to examine the long term impact of European settlement on structural outcomes and therefore to avoid noise coming from current shocks. The indicators of permanent income that I can compute concern different dimensions of districts welfare. First, the educational performances are captured by three indicators: the literacy rate among individuals aged 15 or more; the proportion of individuals aged 7 or more having attended primary school at least one year in their life; the proportion of individuals aged 12 or more having attended secondary school at least

Please refer to Appendix 1 for more detail about data sources.

Districts count on average 450 households, 620 7-12 year old children and 370 less than 5 year-old children. 
one year in their life. Second, the health environment is captured by the proportion of children aged 5 or less suffering from stunting. I used international standards associated to each age (measured in months) to calculate the rate of stunting children in each district. A child is said to suffer from stunting if her height is less than two standard deviations under the median height. The Mauritanian survey does not contain information about children height so Mauritanian districts are excluded from these statistics and all related regressions. Third, access to infrastructures is captured by the proportion of households connected to electricity, the proportion of households having access to a private water tap and the proportion of households using a modern combustible (gas or electricity) for cooking. Finally, the household wealth is also captured by the quality of their housing measured by the proportion of households living in a home with solid walls (cement or hard bricks) and the proportion of households living in a home with a solid roof (cement or tiles). Summary statistics on these development indicators are presented in Table 1.

\subsection{OLS estimates of the impact of European settlement on current performances}

I compare districts development performances according to European settlement in 1925 by running ordinary least squares regressions of the form:

$$
\mathrm{Y}_{\mathrm{i}}=\alpha+\beta \mathrm{E}_{\mathrm{i}}+\mathrm{P}_{\mathrm{i}} \gamma+\mathrm{S}_{\mathrm{i}} \mu+\mathrm{X}_{\mathrm{i}} \lambda+\varepsilon_{\mathrm{i}}
$$

where $\mathrm{Y}_{\mathrm{i}}$ is an outcome variable in district $i, \mathrm{E}_{\mathrm{i}}$ is the number of Europeans in district $i$ per 1,000 population in $1925, \mathrm{P}_{\mathrm{i}}$ a set of proxies for pre-colonial economic prosperity in district $i, \mathrm{~S}_{\mathrm{i}}$ a set of proxies for pre-colonial political status of district $i$ and $X_{\mathrm{i}}$ a set of geographical controls variables. My coefficient of interest is $\beta$ which represents the impact of European settlement net of its correlation with pre-colonial economic, political and geographical characteristics.

Table 5, panels $A$ and $B$ give evidence that European settlement had a very strong positive impact on current performances. Coefficients on Europeans per 1,000 inhabitants in 1925 in panel $B$ show that for one additional European per 1,000 inhabitants in 1925, the current performances rates go up by 0.50 to 2 percentage points. A one standard deviation increase in the number of Europeans per 1,000 inhabitants would produce an approximately one standard deviation increase in current performance rate (from 0.5 to 1.20 depending on which performance is considered). Panel $A$ also shows that the variance in European settlement in 1925 explains in most cases a large part of the variance in current performances.

This methodology produces upwardly biased estimates if there are unobserved districts' characteristics that are correlated with current performances and were likely to influence positively European settlement. The estimates are on the contrary downwardly biased if those characteristics influence negatively European settlement, which is also plausible because "good" characteristics for development path increased hostility towards colonial power and therefore dissuaded Europeans from settling. Despite my effort to capture both economic prosperity through population density, trade counters and desert-edge areas, political development through kingdoms and amorphous areas and geography, omitted variables could bias these estimates.

\subsection{IV estimates of the impact of European settlement on current performances}

A way of solving the problem of omitted variables is to instrument the number of European settlers. This problem has already found some solutions in previous papers, especially in Acemoglu, Johnson and Robinson (2001, 2002) and Feyrer and Sacerdote (2007). Feyrer and Sacerdote (2007) use wind speed as a random source of variation in the length of colonialism, which is obviously unemployable out of the context of islands. Acemoglu, Johnson and Robinson (2001, 2002) use European settler mortality as an exogenous source of variation of European settlement. To use the same instrument, I need settler mortality rates at the district level. I therefore collected data from French national archives on districts mortality (colonial censuses report the number of Europeans in the district and the 
number of deaths over the year). But the problem with settler mortality in West African districts comes from the very small number of Europeans per district. In 1925 for instance, half of the districts have less than 23 Europeans settlers. Only 25 percent of the districts had more than 80 settlers. Such small numbers of settlers produce very volatile and unrepresentative mortality rates. At the national level, settler mortality rates can be calculated on the basis of larger number of European settlers, which gives more reliable data. Graph 2 represents the values of settler mortality rates at the colony level between 1912 and 1947. It is apparent that national settler mortality rates are also volatile from year to year, in a range of 0 to 6 percent. Data from colonial censuses gives thus much lower settler mortality than the data used in Acemoglu, Johnson and Robinson (2001). The average national mortality rates are also very close one from another. The conclusion is that settler mortality rates as observed by the colonial records were not sufficiently different within former French West Africa to explain differences in European settlement.

I use hostility towards colonial power as an instrument for European settlement. The underlying assumption is that hostility towards colonial power affected European settlement (as shown in section II) but did not affect directly long term development path. Since such an assumption is hard to believe given the potential endogenous nature of hostility (discussed below), I will relax it and assume that conditionally on some observable characteristics affecting both hostility and current performances, hostility towards colonial power was something accidental that created exogenous variations in European settlement. I will thus discuss first the "endogenous part" and then the "exogenous part" of hostility.

Hostility could violate the exclusion relation in two ways: first if hostility depended on pre-colonial district characteristics which influenced long term development path (something that preceded colonial experience); second if hostility created particular conditions in the districts which influenced long term development paths independently from European settlement (something that followed colonial experience). Some economic and politic pre-colonial characteristics potentially determined both hostility and development path: hostile areas could be more or less prosperous, more or less politically structured. Hostility could also have created some particular conditions influencing development path independently from European settlement: fighting against colonial power could have been a factor of unity for local population, creating good externalities on long term development thanks to greater collective action and social cohesion (Banerjee, Iyer and Somanathan, 2006). An observable variable that can proxy this kind of positive externalities is the involvement of local chiefs in districts management: hostility could influence the way French administrator rely on local chiefs (direct versus indirect rule). In hostile areas, the intermediation of local chiefs could actually offer a good alternative to direct rule, local people being less reluctant to local chiefs' commandment than to French commandment. The general picture that emerges from the existing literature is that the association of local chiefs tended to produce positive effects on long run development path (Iyer, 2005).

To test the influence of pre-colonial economic prosperity and pre-colonial political status on hostility as well as the potential correlation between hostility and local chiefs association, I run regressions of the form:

$$
\mathrm{H}_{\mathrm{i}}=\alpha+\mathrm{P}_{\mathrm{i}} \gamma+\mathrm{S}_{\mathrm{i}} \mu+{ } \mathrm{C}_{\mathrm{i}}+\mathrm{X}_{\mathrm{i}} \lambda+\varepsilon_{\mathrm{i}}
$$

where $\mathrm{H}_{\mathrm{i}}$ is the measure of hostility in district $i, \mathrm{P}_{\mathrm{i}}$ a set of proxies for pre-colonial economic prosperity in district $i, \mathrm{~S}_{\mathrm{i}}$ a set of proxies for pre-colonial political status of district $i, \mathrm{C}_{\mathrm{i}}$ the amount of local chiefs' wages ${ }^{14}$ in district $i$ and $\mathrm{X}_{\mathrm{i}}$ a set of geographical controls variables.

Empirical results (reported in Appendix table 1) show that hostility was significantly higher in more densely populated areas and in desert-edge areas. Economic prosperity was therefore a factor

14 The colonial budgets report the amount of local chiefs' wages, which is a good proxy for the number and the tribute of local chiefs the colonial power rely on. 
encouraging resistance and hostility, probably because the prosperous areas had more to defend and fight for than poor areas. Notice that former trade counters were not particularly hostile, probably because of the pre-existing contact between Europeans and Africans in these specific localities. Precolonial political development also influenced hostility towards colonial power: kingdoms were more hostile than the rest of the region. It is interesting that economic prosperity and political organisation both independently influence positively hostility towards colonial power. What is also interesting is that empirical evidence is consistent with historians' observations on the fact that amorphous areas were also very hard to control, because of the lack of social authority on which colonial power could rely on. The coefficient on amorphous areas dummy is positive and very significant. There is thus a non-linear relationship between hostility and political status, the most hostile areas being the most and the least politically structured areas. There is also empirical evidence of a positive correlation between hostility and local chiefs association: in hostile areas, the colonial administration tended to rely more on local chiefs. It is also worth noting that the significantly positive coefficient on latitude probably reflects a correlation between Islam and hostility, which is recurrently mentioned in administrators' annual reports ${ }^{15}$. In these reports, it is also often mentioned that hostility was associated with cultural and social cohesion. Districts with high level of ethnic fractionalization were actually less likely to mobilize and fight against French power due to their lack of leadership and cohesion. Related to this, it was easier for French administrators to instrument the existing social divisions in fragmented districts to impose the colonial rule ("Divide and Rule"). Hostility was thus evidently correlated with intrinsic district characteristics that also potentially influenced (positively) their development path.

But African historians and administrators' annual reports also give evidence that district characteristics did not explain the totality of differences in hostility. At least a part of hostility might come from a mismatch between a specific colonial administrator and African people at the beginning of colonial times. Cohen (1974) documents the heterogeneity of French colonial administrators as regard to their educational background and their vision of colonialism. Some colonial administrators were more diplomat than others and could succeed in creating a favourable political climate with local people, whereas others more brutal could provoke aggressive reactions. Another accidental source of hostility could be the emergence of a specific leader personally inclined to resistance towards colonial authority due to absolutely personal dispositions. Administrators reported cases where chiefs accepted some indemnities whereas others declined the same offer because of their different personality and inclination towards opposition. An example that illustrates such variations can be found with the two neighbouring Bambara kingdoms, Kaarta and Segu: the Fama Mademba of Segu accepted to collaborate and to receive an annual indemnity from the colonial power whereas the king of Kaarta, Koulibaly, declined. Consequently, the level of hostility in the corresponding districts was much higher in the former Kaarta than in the former Segu. Another example is Sine Saloum and Baol in Senegal: they are neighbouring districts, both densely populated, both under a pre-colonial kingdom, with very similar anthropological and geographical characteristics. Baol was significantly more hostile than Sine Saloum: the average annual number of severe events expressing hostility was 0.6 in Baol and 0.2 in Sine Saloum. We can also consider Ouahigouya and Dedougou in current Upper-Volta, both part of the Mossi society. Dedougou caused many problems to the colonial administrators over 1906-1920 (1 severe event expressing hostility per year) whereas Ouahigouya was a rather calm district ( 0.2 severe events expressing hostility per years). I thus argue that conditionally to observable characteristics that capture main pre-colonial differences, hostility towards colonial power was something accidental that constituted an exogenous source of variation in European settlement.

IV estimates of the impact of European settlement on current performances are reported in table 5, panel $C$. The partial R-squared associated to this instrumentation strategy is 0.33 so I avoid potential small sample bias caused by the use of weakly correlated instruments. Instrumental variable point estimates are not significantly different from OLS point estimates. The usual prediction that OLS estimates are upwardly biased is thus not verified here. Europeans did not systematically settled in best

\footnotetext{
${ }^{15}$ Islam penetration came historically from North Africa and is therefore north-to-south distributed.
} 
performing areas, as illustrated by the fact that some factors as hostility could prevent them from settling.

Finally, it is worth noting that unobserved districts characteristics positively correlated with both hostility and current performances produce downwardly biased estimates of the impact of European settlement on current performances. My IV estimates of the impact of European settlement on current performances are therefore likely to be a lower bound of the true impact. The use of distance from the nearest seaport is an alternative instrument for European settlement, since it was actually negatively correlated with European settlement because all settlers arrived from Europe in West Africa by boat and were therefore more likely to settle near the port they drew along. This alternative instrument is far from perfect since distance to the nearest seaport is highly correlated to distance to the coast, which in turn reflects intrinsic ability to advance economically in the modern age due to low transportation costs for trade. To reduce the upward bias due to the direct impact of distance from the nearest seaport on current outcomes, I run 2SLS on coastal districts only (21 districts). Appendix Table 2 reports the IV estimates using distance from the nearest seaport as an alternative instrument for the number of Europeans per 1,000 inhabitants in 1925 both on the whole sample and on coastal districts only. These estimates are significantly higher than those using hostility towards colonial power over 1906-1920 as an instrument (especially on the whole sample), which confirms the intuition that using hostility as an instrument might downwardly bias the estimates of the impact of European settlement on current outcomes due to the positive correlation between hostility and the general ability to develop that I do not entirely capture with the observable controls (especially prevalence of Islam and social cohesion). Facing the challenge to find a random source of variation of European settlement, it is at least more cautious to use hostility over 1906-1920 than more classical instruments such as geographical features.

To conclude on the impact of European settlement on current performances, my estimates provide support to the fact that colonized areas that received more European settlers have better performances than colonized areas that received less Europeans settlers. Again I claim that these results do not mean that colonization per se was a good experience, since I do not compare colonized versus non colonized areas but colonized areas with many Europeans versus colonized areas with few Europeans.

\section{WHY DID EUROPEAN SETTLEMENT PLAY A POSITIVE ROLE?}

\subsection{Institutional channels}

The positive impact of European settlement in former colonies has already been explored, especially in Acemoglu, Johnson and Robinson (2001). In this paper, the authors show that the relationship between European settlement and current performances works through the quality of the institutions brought by Europeans. Europeans adopted different colonization policies in different colonies with different associated institutions. At one extreme, in places where the disease environment was not favourable to European settlement, Europeans set up extractive institutions characterized by little protection of private property and checks against government expropriation. At the other extreme, in places where the disease environment was favourable to European settlement, Europeans migrated and created what the historian Alfred Crosby (1986) calls "Neo-Europes", primarily Australia, New Zealand, Canada and the United States. In these colonies, the settlers tried to replicate European institutions with strong emphasis on private property and checks against government expropriation. As regard to the way institutions encourage productive activities, capital accumulation, skill acquisition and invention, the extractive strategy was associated to "bad" institutions whereas the settlement strategy was associated to "good" institutions. They use the protection against risk of expropriation index from Political Risk Services, the constraint on Executives index and the democracy index from Polity III dataset as proxies for the quality of institutions.

There is no measure of the quality of institutions at the infra-national district level. I therefore cannot test directly the validity of this potential explanation within former French West Africa. The question is de facto slightly different within former French West Africa since the global colonization policy 
("extraction" versus "migration") was homogenous all over the region. In former French West Africa, Europeans only pursued an extractive strategy. Therefore, the potential variations in the quality of institutions, if any, could not come from differences in colonial strategy. The question here is thus why European settlement had a positive impact on current development conditionally to their extractive strategy. We could be surprised that the impact of European settlement was positive given the bad nature of the institutions they implemented.

Within former French West Africa, the risk of expropriation, constraint on Executives and political participation of local population were formally driven by the same set of rules since the legal system was uniform all over the region ${ }^{16}$. Colonial rules were defined by the General Governor of the whole French West Africa, if not by the Minister of the Colonies for the whole French empire. The administrative organization was remarkably homogenous, as were the economic and social rules. If differences in European settlement created some differences in institutions, it should therefore be related to the application of colonial rules, not to colonial rules themselves. I adopt the definition of institutions as "sets of rules, compliance procedures and moral and ethical behavioural norms that constrain the behaviour of individuals" (North (1981)). With respect to this definition, de jure institutions within colonial French West Africa did not differ except for exceptional towns in Senegal. But this does not prevent from de facto variations. For instance, African people living close to many European settlers could take a greater advantage of the new legal code than people living in sparsely settled areas, where customary law was more likely to compete with colonial rules. Aldashev, Chaara, Platteau and Wahhaj (2007) show examples of situations where formal and informal laws are seen as conflicting with each other. The general picture that emerges from the literature is that legal pluralism tends to produce neutral or negative effects. I consciously leave aside this question because I can not give any empirical evidence of such differences. I can only argue that the positive impact of European settlement within former French West Africa did not run through the quality of formal institutions, and that the bad nature of institutions brought by colonizers gives little support to an institutional explanation of the positive role of European settlers on current outcomes.

\subsection{The role of private and public investments}

Another potential explanation of the fact that European settlement had a positive impact on current performances is that Europeans increased investments in areas where they were installed, simply because Europeans were themselves administrators, businessmen or missionaries and had capital that African people almost lacked for major investments. The mechanism running behind the previous findings could be therefore far more direct than the one stressed by the broad literature on institutions: the key determinant of the positive impact of European settlement could be the investments themselves rather than the incentives to invest created by a more favourable institutional environment. On the private side, Europeans invested in resource extraction (peanuts, vegetable oils, wood, cotton, leather, cocoa, coffee tree, minerals). Private investors were likely to introduce new crops and new techniques to increase total yields that could be channelled into exports. On the public side, Europeans invested in public goods such as education (building schools and paying teachers), health (building hospitals and dispensaries and paying doctors and nurses) and infrastructures (roads, wells, bridges, harbours, railways, air transport). Note that all public expenses were financed by local tax revenue and not by European taxpayers. These investments created new job opportunities for local people, some improvements in agricultural productivity and a greater access to human capital formation, which could be the key reason why regions with numerous Europeans settlers grew faster than regions with few ones.

Unfortunately I have no district level data on private investments neither during the colonial era nor today. The only empirical evidence I can bring is on public investments: I collected district level data

16 Except the four «communes » (Saint-Louis, Dakar, Rufisque and Goree), whose inhabitants were French citizens. Some fiscal rules were also different in these cities. 3 of them are excluded from my empirical study (Goree, Dakar, Dakar and Saint-Louis). 
on colonial public investments in education, health and infrastructures from annual colonial budgets ${ }^{17}$ so I can test if differences in European presence within French West Africa are correlated with differences in access to public goods. For further detail on data on colonial public investments, I refer to Huillery (2007). In Huillery (2007), I give evidence that early colonial investments in education, health and public works had large and persistent effects on current outcomes. The impact of colonial investments in education, health and public works on current district development is statistically significant, positive and sizeable, and is not driven by the presence of Europeans in the districts since Europeans were included as a control in every regression. We can ask whether the number of European settlers and colonial public investments were highly correlated and whether this relationship explains the positive impact of European settlers on current performances.

Graphs 13, 14 and 15 show the correlation between the number of European settlers in 1925 per 1,000 population and colonial public investments in teachers, doctors and infrastructures over 1910-1928. This finding cannot be taken as conclusive evidence that European settlers caused differences in colonial public investments. An alternative explanation that is just as plausible is that Europeans had incentives to settle in areas with high colonial public investments, as noted by Curtin (1995, p. 447): "Settlers tended to follow capital investment in technologically complex enterprises". This potential reverse causation is not a crucial issue for the purpose of this paper, which is to explain why areas with a higher concentration of European settlers in 1925 are more developed today, all other things being equal. Since European settlement and colonial public investments largely worked together, I just point out that the positive influence of European settlement on current performances can reflect the positive influence of colonial public investments.

A simple empirical test consists in including colonial public investments in regression (4). I compare districts development performances according to European settlement in 1925 and colonial public investments by running ordinary least squares regressions of the form:

$$
\mathrm{Y}_{\mathrm{i}}=\alpha+\beta \mathrm{E}_{\mathrm{i}}+\pi \mathrm{I}_{\mathrm{i}}+\mathrm{P}_{\mathrm{i}} \gamma+\mathrm{S}_{\mathrm{i}} \mu+\mathrm{X}_{\mathrm{i}} \lambda+\varepsilon_{\mathrm{i}}
$$

where $\mathrm{Y}_{\mathrm{i}}$ is an outcome variable in district $i, \mathrm{E}_{\mathrm{i}}$ is the share of Europeans in district $i$ population, $\mathrm{I}_{\mathrm{i}}$ is the colonial investments corresponding to $Y_{i}$ (teachers for $Y_{i}$ related to education, doctors for $Y_{i}$ related to health and public works for $Y_{i}$ related to infrastructures), $P_{i}$ a set of proxies for pre-colonial economic prosperity in district $i, \mathrm{~S}_{\mathrm{i}}$ a set of proxies for pre-colonial political status of district $i$ and $\mathrm{X}_{\mathrm{i}}$ a set of geographical controls variables. My coefficients of interest are $\beta$ which represents the impact of European settlement and $\pi$ which represents the impact of colonial public investments, net of both their mutual correlation and their correlation with pre-colonial economic prosperity, political statuses and geographical factors.

Table 7 shows that the colonial public investments partly explain the positive relationship between European settlement and current performances. But they do not capture the whole effect of European settlement, except for health outcome. For most of outcomes, both European settlement and public investments influenced positively current performance rates. The size of the coefficients on European settlement decreases, showing that previous estimates of European settlement partly captured the effect of colonial public investments.

To conclude, I can only argue that the positive influence of European settlement on current performances is partly explained by colonial public investments in education, health and infrastructures. This explanation leaves space to other additional channels that I am not able to measure, like variations in private investments (very likely) or de facto institutions.

\footnotetext{
17 The annual colonial budgets are in the Archives Nationales in Dakar, Senegal.
} 


\section{DID PROSPEROUS PRE-COLONIAL AREAS FALL BEHIND?}

\subsection{An overall change in distribution of prosperity?}

The final question that I want to examine is whether the colonial experience created a reversal of fortune within former French West Africa, following Acemoglu, Johnson and Robinson (2002) who observe - at the world wide level - that the most prosperous pre-colonial areas in 1500 became the least prosperous in 2000 .

To test this reversal of fortune, I use the straightforward strategy used in Acemoglu, Johnson and Robinson (2002): I compare districts development performances according to pre-colonial economic prosperity by running ordinary least squares regressions of the form:

$$
\mathrm{Y}_{\mathrm{i}}=\alpha+\mathrm{P}_{\mathrm{i}} \gamma+\mathrm{S}_{\mathrm{i}} \mu+\mathrm{X}_{\mathrm{i}} \lambda+\varepsilon_{\mathrm{i}}
$$

where $\mathrm{Y}_{\mathrm{i}}$ is an outcome variable in district $i, \mathrm{P}_{\mathrm{i}}$ a set of proxies for pre-colonial economic prosperity in district $i, \mathrm{~S}_{\mathrm{i}}$ a set of proxies for pre-colonial political status of district $i$ and $\mathrm{X}_{\mathrm{i}}$ a set of geographical controls variables. My coefficient of interest is $\gamma$ which represents the correlation between pre-colonial and current economic performances.

Table 8 reports the results. Coefficients on pre-colonial economic prosperity variables are all positive or neutral. The relationship between pre-colonial and current economic performances is therefore not very strong. But the general patterns do not give any evidence of a reversal of fortune. The colonial experience rather altered the distribution of prosperity within former French West Africa than changed it.

This positive or neutral relationship between pre-colonial and current economic performances indeed reflects the fact that some of the richest pre-colonial areas are no longer richer than the others, but they are not less rich. Other areas less prosperous before colonial times have been favoured by colonial power and therefore caught up with the most prosperous. This result is also consistent with the mechanism driving European settlement: as predicted by Acemoglu, Johnson \& Robinson (2002), Europeans preferred prosperous areas in West Africa because the profitability of extraction was higher in prosperous areas than in poor ones. With respect to this factor, Europeans thus tended to reinforce pre-colonial inequalities by settling in prosperous areas. But on the other hand, hostility towards colonial power was more severe in prosperous areas and dissuaded Europeans from settling. These two mechanisms tended to compensate and therefore did not reverse completely the distribution of prosperity.

\subsection{How much did hostile areas lose?}

Using previous estimates of the impact of European settlement on current performances, I examine the loss in current development caused by hostility. To do so, I first calculate the loss in European settlers caused by hostility. The loss in European settlers is the difference between the effective number of Europeans settlers in 1925 and a counterfactual number of European settlers corresponding to what our estimates in equation (2) predict without hostility. Equation (2) gives estimates of the impact of pre-colonial economic prosperity, pre-colonial political development and geography on European settlement nets from their correlation with hostility:

$$
\mathrm{E}_{\mathrm{i}}=\alpha+\delta \mathrm{H}_{\mathrm{i}}+\mathrm{P}_{\mathrm{i}} \gamma+\mathrm{H}_{\mathrm{i}} * \mathrm{P}_{\mathrm{i}} v+\mathrm{S}_{\mathrm{i}} \mu+\mathrm{X}_{\mathrm{i}} \lambda+\varepsilon_{\mathrm{i}}
$$

By equalling $\mathrm{H}_{\mathrm{i}}$ to zero, I calculate the counterfactual number of European settlers without hostility $\mathrm{E}^{*}$.

$\mathrm{E}^{*}{ }_{\mathrm{i}}-\mathrm{E}_{\mathrm{i}}$ is the loss in European settlers caused by hostility in district $i$. Graph 2 shows the loss in European settlers caused by hostility: the more distant to the $45^{\circ}$ line, the larger loss. On average, 
West African districts lost 2.8 Europeans per 1000 inhabitants in 1925 because of hostility. The district of Porto-Novo, which was both economically attractive and much hostile, should receive 47 European settlers per 1000 inhabitants more in 1925 had its population not been hostile, which represents approximately 10,000 European settlers. The European settlers in Casamance in 1925 would have been 2,600 rather than 200 had this district not been so hostile. Other districts like Conakry, Timbuktu, Nema, Agadez also lost many Europeans.

Second, I use the counterfactual number of European settlers that districts would have received had they not been hostile to calculate the corresponding performance rates. I simply replace $E_{i}$ by $E^{*}{ }_{i}$ in equation (4). Graphs 4 to 12 show the loss in current performance rates caused by hostility through the loss in European settlement. Here again, the more distant to the $45^{\circ}$ line, the larger the loss. The average differences between the counterfactual and the effective performance rates in 1995 are between 2 and 7 percentage points, depending on which outcome is considered. But this average includes non hostile districts, which did not loss anything. If we consider the top tercile of hostility (H3) distribution, the estimated loss is large: performance rates would grow up from 5 to 14 percentage points, depending on which outcome is considered, had the districts not been hostile. Hostility towards colonial power had thus a large and persistent negative impact, especially for precolonial prosperous areas for which the loss in European settlers caused by hostility was particularly sensitive.

\section{CONCLUSION}

Many economists and social scientists believe that differences in colonial experience are at the root of large differences in current outcomes across countries. This paper explored the impact of colonial experience within a more homogenous area so as to bring a better understanding of underlying mechanisms. The main results of this paper are: (1) European settlers preferred prosperous areas within West Africa, which is consistent with Acemoglu, Johnson and Robinson (2002) premises since the general colonial policy was "extraction". Europeans thus tended to reinforce pre-colonial inequalities by settling in prosperous areas. (2) This preference towards prosperous areas was discouraged by hostility towards colonial power. Hostility actually dissuaded Europeans from settling and the consequence is that rich but hostile areas thus received less Europeans settlers than rich and not hostile areas. When hostility was really severe in a prosperous area, Europeans preferred to settle in a calm neighboring area even if it was less prosperous. (3) Colonized and highly settled areas had faster development paths than colonized and poorly settled areas. The impact of European settlement was thus positive even in an "extractive" colonization context, working partly through colonial public investments: the higher the number of European settlers, the higher the level of colonial investments in education, health and infrastructures. (4) The distribution of prosperity within former French West Africa did not reverse. But changes affected hostile areas which did not become the poorest in the region but lost a part of their pre-colonial advantage. Other calm areas caught up with them and sometimes overhung. Differences in hostility towards colonial power thus explain why some changes in the prosperity distribution occurred within former French West Africa. It throws light on the emergence of new dynamic areas like Cotonou, Niamey, Bassam, Abidjan, Dakar, Conakry, PortEtienne, Bamako, Thies or Kaolack, and the relative decline of some of the most pre-colonial dynamic areas like Porto-Novo, Abomey, Fuuta-Djalo, Kankan, Agadez, Timbuktu, Casamance, Waalo, Fuuta Toro, Macina or Hausa land. 


\section{REFERENCES}

Acemoglu, Daron, Simon Johnson, James A. Robinson (2001), "The colonial origins of comparative development: an empirical investigation", American Economic Review, 91(5), 1369-1401.

- (2002), "Reversal of fortune: Geography and Institutions in the Making of the Modern World Income Distribution", Quaterly Journal of Economics, 117, 1231-1294.

Acemoglu, Daron, Simon Johnson (2003), "Unbundling institutions", NBER Working Paper No. 9934.

Aldashev, Gani, Imane Chaara, Jean-Philippe Platteau and Zaki Wahhaj (2007), "The Custom in the Shadow of the Formal Law: An Economic Analysis", Working Paper, CRED, University of Namur.

Austin Gareth (2008), "Resources, Techniques and Strategies South of the Sahara, Revising the Factor Endowments Perspective on African Economic Development, 1500-2000", forthcoming in the Economic History Review.

Bairoch, Paul (1993), "Economics and World History, Myths and Paradoxes", University of Chicago Press.

Banerjee, Abhijit, Lakshmi Iyer (2005), "History, Institutions and Economic Performance: the legacy of colonial tenure systems in India", American Economic Review, 95(4), 1190-1213.

Banerjee, Abhijit Lakshmi Iyer and Rohini Somanathan (2006), "Public Action for Public Goods", forthcoming in Handbook of Development Economics, vol. 4.

Barrett, G. (1967), "Schism and Renewal in Africa”, New York, Columbia University Press.

Bertocchi, Graziella, Fabio Canova (2001), "Did colonization matter for growth? An empirical exploration into the historical causes of Africa's underdevelopment", European Economic Review, 46, 1851-1871.

Boahen, Adu A. (sous la direction de) (1990), «L'Afrique sous la domination coloniale : 1885-1935 », in Histoire générale de l'Afrique, vol VII, 1990, UNESCO/NEA.

Bouche, Denise (1991), « Histoire de la colonisation française », Fayard, Paris.

Brown, David S. (2000), "Democracy, colonization and human capital in sub-saharian Africa", Studies in Comparative International Development, 35(1).

Cogneau, Denis (2003), "Colonization, school and development in Africa, an empirical analysis", DIAL, DT/2003/01.

Cogneau, Denis, Charlotte Guénard (2003), "Colonization, institutions and inequality, a note on some suggestive evidence", DIAL, DT/2003/05.

Cohen, William B. (1974), «Empereurs sans sceptre, histoire des administrateurs de la France d'Outre-mer et de l'Ecole coloniale », Berger-Levrault, Paris.

Coquery-Vidrovitch, Catherine, Henri Moniot (1993), "L'Afrique Noire de 1800 à nos jours », Presses Universitaires de France, Paris.

Crowder, Michael (1968), "West Africa under colonial rule”, Northern University Press 
- (1971), "West African resistance, the military response to colonial occupation", Hutchinson of London, London.

Crowder, Mickael, Obaro Ikime (1970), "West African chiefs: their changing status under colonial rule and independence", Africana Publications, New York.

Crosby Alfred (1968), "Ecological Imperialism; The Biological Expansion of Europe 900-1900”, New York: Cambridge University Press.

Curtin, Philip, Steven Feierman, Leonard Thompson, Jan Vansina (1995), "African history from earliest times to independence", Longman Group Limited.

Diamond, Jared (1997), “Guns, Germs, and Steel, The Fate of Human Societies", W.W. Norton \& Company, March 1997.

Engerman, Stanley L., Kenneth L. Sokoloff (1997), "Factor Endowments: Institutions, and Differential Paths of Growth Among New World Economies: A View from Economic Historians of the United States", in Stephen Haber, How Latin America Fell Behind, Stanford: Stanford University Press.

- (2002), "Factor Endowments, Inequality and Paths of Development Among New World Economies", NBER Working Paper No. 9259.

- (2005), "Colonialism, inequality and long-run paths of development", NBER Working Paper No 11057.

Englebert, Pierre (2000), "Pre-colonial Institutions, Post-colonial States and Economic Development in Tropical Africa", Political Research Quaterly, 53, 1-30.

Feyrer James, Bruce Sacerdote (2007), "Colonialism and Modern Income - Islands as Natural Experiments", forthcoming in the Review of Economics and Statistics.

Frankema E.H.P. (2005), "The colonial origins of inequality: exploring the causes and consequences of land distribution", Ibero America Institute for Econ. Research (IAI) Discussion Papers No. 119.

Gennaioli, Nicola and Rainer, Ilia (2007), "The modern impact of precolonial centralization in Africa", Journal of Economic Growth.

Hall, Robert E., Charles I. Jones (1999), "Why do some countries produce so much more output per worker than others?”, Quarterly Journal of Economics, Vol. 114, No. 1, 83-116.

Herbst, Jeffrey (2000), "States and power in Africa”, Princeton University Press, Princeton.

Hilling, David (1969), "The Evolution of the Major Ports of West Africa", The geographical Journal, Vol. 135, No. 3, pp. 365-378.

Hoff, Karla (2003), "Paths of institutional development: a view from economic history", The World Bank Research Observer, Oxford University Press.

Huillery, Elise (2007), "History matters: the long term impact of colonial public investments in French West Africa", forthcoming in the American Economic Journal - Applied Economics.

Iyer Lakshmi (2005), "The long-term impact of colonial rule: evidence from India", Harvard University, Harvard Business School Working Paper No. 05-041.

Ki-Zerbo, Joseph (1978), « Histoire de l’Afrique Noire », d'Hier à Demain, Hatier, Paris. 
Malthus, Thomas (1798), "An Essay on the Principle of Population, as it Affects the Future Improvement of Society with Remarks on the Speculations of Mr. Godwin, M. Condorcet, and Other Writers London", printed for J. Johnson in St. Paul's Church-Yard.

McEvedy, Colin and Richard Jones (1975), "Atlas of World Population History”, Facts on file, New York.

Morrison, Donald, R. Mitchell and J. Paden (1989), "Black Africa: A Comparative Handbook", New York: Paragon House.

Murdock, G. (1967), "Ethnographic Atlas”, Pittsburgh, University of Pittsburgh Press.

North, Douglass C. (1981), "Structure and Change in Economic History”, NewYork, Norton \& Co.

- (1990), "Institutions, Institutional change, and Economic Performance", Cambridge University Press, New York.

Nunn, Nathan (2008), "The Long Term Effects of Africa's Slave Trades", forthcoming in the Quarterly Journal of Economics.

Pande Rohini, Christopher Udry (2005), "Institutions and Development, A view from Below", forthcoming in the Proceedings of the 9th World Congress of the Econometric Society, edited by R. Blundell, W. Newey, and T. Persson, Cambridge University Press.

Quy Toan Do, Lakshmi Iyer (2002), "Lands right and economic development: evidence from Viet Nam”, World Bank Policy Research Working Paper No. 3120.

Rioux, Jean-Pierre (sous la direction de) (2007), « Dictionnaire de la France Coloniale », Flammarion, Paris.

Rodrik, Dani, Arvind Subramanian, Francesco Trebbi (2002), "Institutions rule: the primacy of institutions over geography and integration in economic development", Harvard.

Sachs, Jeffrey and Andrew Warner (1997), "Natural Resource Abundance and Economic Growth", Development Discussion Papers, $\mathrm{n}^{\circ}$ 517a, Harvard Institute for International Development.

Sokoloff, Kenneth L. \& Stanley L. Engermann (2000), "History Lessons: Institutions, Factor Endowments, and Paths of Development in the New World", Journal of Economic Perspectives, $14,217-232$.

Stevenson, Robert F. (1968), "Population and Political Systems in Tropical Africa", New York and London: Columbia University Press. 


\section{APPENDICES}

\section{Appendix 1: Data description and sources}

Variable

\begin{tabular}{l} 
Population density \\
\hline Desert-edge dummy \\
\hline Trade counter dummy \\
\hline Kingdom dummy \\
\hline Amorphous area dummy \\
\hline Altitude \\
\hline Latitude \\
\hline Longitude \\
\hline Annual rainfalls \\
\hline River dummy \\
\hline Coastal dummy \\
\hline European settlement (1910, 1925 or 1950$)$ \\
\hline Hostility towards colonial power
\end{tabular}

towards colonial powe

\section{Local chiefs wages}

Colonial public investments in education

Colonial public investments in health

Colonial public investments in infrastructures

Literacy ra

Primary school attendance rate

Secundary school attendance rate

Access to a private water tap

otal population divided by total land

1 if the district is located at the desert-edge, 0 otherwise

1 if the district was part of a pre-colonial kingdom, 0 otherwise

1 in case of total absence of pre-colonial political authority, 0 otherwise

Altitude of the main town in the district, in meter

Mean of the latitude of the households in the district

Average annual rainfalls in mm over 1915-1975

1 if the district has a navigable river, 0 otherwise

1 if the district is on the coast, 0 otherwise

Number of European settlers per 1,000 inhabitants (in 1910, 1925 or 1950)

Occurrence rate of events expressing hostility (H1), occurrence rate

of severe events expressing hostility $(\mathrm{H} 2)$ and average annual

number of severe events expressing hostility ( $(H 3)$.

Average annual wages to local chiefs paid on public budget over 1910-1928

Average annual number of teachers paid on public budget over 1910-1928

Avver of doctors paid on public budget over 1910-1928

Percentage of more than 15-year-old literate individuals

Percentage of more than 7-year-old individuals who attended

primary school at least one year in their life

Percentage of more than 13-year-old individuals who attended

secundary school at least one year in their life

Percentage of households having access to a private water tap

Connected to electricity

Percentage of households being connected to electricity

Using a modern combustible

Percentage of households using a modern combustible

(gas or electricity)

Wall solidity

Percentage of households living in a house with solid walls (ciment or bricks)

Roof solidity

Percentage of households living in a house with a solid roof (ciment or tiles)

Stunting rate

Percentage of less than 5-year-old children with height less than

2 standard deviations under the international median height
Source

(Archives Nationales, Paris, France, série G, sous-série 22)

and maps (Documentation Francaise, Paris, France)

FAO map on http://www.fao.org/farmingsystems/FarmingMaps/SSA/12/AL/map/m10000.html Hilling (1969)

Same sources as in Appendix 2

Website http://fallingrain.com/world

Website http://fallingrain.com/world

Website http://fallingrain.com/world

ORSTOM records

Colonial maps, 1925, Documentaion Francaise, Paris, France

Colonial maps, 1925, Documentation Française, Paris, France

Colonial censuses (Archives Nationales, Paris, France série G, sous-série 22)

(Archives nationales, Paris, France, série G, sous-série 2)

Colonial annual budgets, Archives Nationales, Dakar, Senegal.

Huillery (2007)

Huillery (2007)

Huillery (2007)

(19) (2000) for Senegal, EIBC (1994) for Guinea

EPCV (1995) for Mauritania, and QUIBB (2002) for Benin

EPCV (1998) for Upper-Volta, ESAM II (2000) for Senegal, EIBC (1994) for Guinea,

EPCES (1995) for Niger, EMCES (1994) for Mali, EPDS (1993) for lvory Coast,

EPCV (1995) for Mauritania, and QUIBB (2002) for Benin

EPCV (1998) for Upper-Volta, ESAM II (2000) for Senegal, EIBC (1994) for Guinea,

EPCES (1995) for Niger, EMCES (1994) for Mali, EPDS (1993) for lvory Coast,

EPCV (1995) for Mauritania and OUIBB (2002) for Benin

EPCV (1998) for Upper-Volta, ESAM II (2000) for Senegal, EIBC (1994) for Guinea,

EPCES (1995) for Niger, EMCES (1994) for Mli, EPDS (1993) for tvory Coast,

EPCV (1995) for Mu, EMCES (1904) Tor Mal, EPDS (199)

EPCV (1995) for Mauritania, and QUIBB (2002) for Benin

EPCES (1995) for Niger, EMCES (1994) Fo Mali, EPDS (1993) fo IV J Coast?

EPCS (195) fOr Niger, EMCES (1094) for Mal, EPDS (1902)

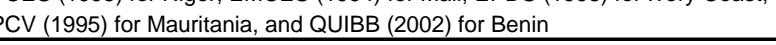

(1994) for Guin

EPCES (1995) for Niger, EMCES (1994) for Mali, EPDS (1993) for Ivory Coast,

EPCV (1995) for Mauritania, and QUIBB (2002) for Benin

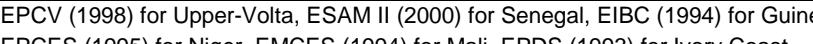

EPCES (1995) for Niger, EMCES (1994) for Mali, EPDS (1993) for Ivory Coast,

EPCV (1995) for Mauritania, and QUIBB (2002) for Benin

EPCV (1998) for Upper-Volta, ESAM II (2000) for Senegal, EIBC (1994) for Guinea,

EPCES (1995) for Niger, EMCES (1994) for Mali, EPDS (1993) for Ivory Coast,

EPCV (1995) for Mauritania, and QUIBB (2002) for Benin

EPCV (1998) for Upper-Volta, ESAM II (2000) for Senegal, EIBC (1994) for Guinea,

EPCES (1995) for Niger, EMCES (1994) for Mali, EPDS (1993) for Ivory Coast,

EPCV (1995) for Mauritania, and QUIBB (2002) for Benin 


\section{Appendix 2: $\quad$ Data on pre-colonial kingdoms}

\begin{tabular}{|c|c|}
\hline District & Related pre-colonial kingdom \\
\hline Bondoukou & Abron \\
\hline Portonovo & Adjatche \\
\hline Baol & Bawol \\
\hline Thies & Bawol \\
\hline Borgou & Borgu \\
\hline Hautegambie & Bundu \\
\hline Abomey & Dahomey \\
\hline Allada & Dahomey \\
\hline Ouidah & Dahomey \\
\hline Adrar & Emirate of Adrar \\
\hline Brakna & Emirate of Brakna \\
\hline Tagant & Emirate of Tagant \\
\hline Trarza & Emirate of Trarza \\
\hline Kindia & Fuuta Jaalo \\
\hline Koumbia & Fuuta Jaalo \\
\hline Labe & Fuuta Jaalo \\
\hline Mamou & Fuuta Jaalo \\
\hline Pita & Fuuta Jaalo \\
\hline Matam & Fuuta Toro \\
\hline Podor & Fuuta Toro \\
\hline Bobodioulasso & Gwiriko \\
\hline Louga & Jolof \\
\hline Nara & Kaarta \\
\hline Nioro & Kaarta \\
\hline Tivaouane & Kajoor \\
\hline Goure & Kanem-Bornu \\
\hline NGuigmi & Kanem-Bornu \\
\hline Sikasso & Kenedugu \\
\hline Kong & Kong \\
\hline Dori & Liptako \\
\hline Fada & Liptako \\
\hline Bandiagara & Macina \\
\hline Gourma & Macina \\
\hline Mopti & Macina \\
\hline Kankan & Samori \\
\hline Kissidougou & Samori \\
\hline Kouroussa & Samori \\
\hline Assinie & Sanwi \\
\hline Macina & Segu \\
\hline Segou & Segu \\
\hline Sinesaloum & Siin Salum \\
\hline Dosso & Sokoto \\
\hline Konny & Sokoto \\
\hline Tessaoua & Sokoto \\
\hline Zinder & Sokoto \\
\hline Tenkodogo & Tenkodogo \\
\hline Dagana & Waalo \\
\hline Kaya & Wagadugu \\
\hline Koudougou & Wagadugu \\
\hline Ouagadougou & Wagadugu \\
\hline Ouahigouya & Yatenga \\
\hline
\end{tabular}

\section{Source}

Coquery-Vidrovitch \& Moniot [1993];Ki-Zerbo [1978]

Coquery-Vidrovitch \& Moniot [1993];Ki-Zerbo [1978]; Curtin [1978]

Coquery-Vidrovitch \& Moniot [1993];Ki-Zerbo [1978]; Curtin [1978]

Coquery-Vidrovitch \& Moniot [1993];Ki-Zerbo [1978]; Curtin [1978]

Bouche [1991];Ki-Zerbo [1978]; Curtin [1978]

Coquery-Vidrovitch \& Moniot [1993]; Curtin [1978]

Bouche [1991]; Coquery-Vidrovitch \& Moniot [1993];Ki-Zerbo [1978]; Curtin [1978]

Bouche [1991]; Coquery-Vidrovitch \& Moniot [1993];Ki-Zerbo [1978]; Curtin [1978]

Bouche [1991]; Coquery-Vidrovitch \& Moniot [1993];Ki-Zerbo [1978]; Curtin [1978]

Coquery-Vidrovitch \& Moniot [1993];Ki-Zerbo [1978]; Curtin [1978]

Coquery-Vidrovitch \& Moniot [1993];Ki-Zerbo [1978]; Curtin [1978]

Coquery-Vidrovitch \& Moniot [1993];Ki-Zerbo [1978]; Curtin [1978]

Coquery-Vidrovitch \& Moniot [1993];Ki-Zerbo [1978]; Curtin [1978]

Bouche [1991]; Coquery-Vidrovitch \& Moniot [1993];Ki-Zerbo [1978]; Curtin [1978]

Bouche [1991]; Coquery-Vidrovitch \& Moniot [1993];Ki-Zerbo [1978]; Curtin [1978]

Bouche [1991]; Coquery-Vidrovitch \& Moniot [1993];Ki-Zerbo [1978]; Curtin [1978]

Bouche [1991]; Coquery-Vidrovitch \& Moniot [1993];Ki-Zerbo [1978]; Curtin [1978]

Bouche [1991]; Coquery-Vidrovitch \& Moniot [1993];Ki-Zerbo [1978]; Curtin [1978]

Coquery-Vidrovitch \& Moniot [1993];Ki-Zerbo [1978]; Curtin [1978]

Coquery-Vidrovitch \& Moniot [1993];Ki-Zerbo [1978]; Curtin [1978]

Ki-Zerbo [1978]

Coquery-Vidrovitch \& Moniot [1993];Ki-Zerbo [1978]; Curtin [1978]

Coquery-Vidrovitch \& Moniot [1993];Ki-Zerbo [1978]; Curtin [1978]

Coquery-Vidrovitch \& Moniot [1993];Ki-Zerbo [1978]; Curtin [1978]

Coquery-Vidrovitch \& Moniot [1993];Ki-Zerbo [1978]; Curtin [1978]

Bouche [1991]; Coquery-Vidrovitch \& Moniot [1993];Ki-Zerbo [1978]; Curtin [1978]

Bouche [1991]; Coquery-Vidrovitch \& Moniot [1993];Ki-Zerbo [1978]; Curtin [1978]

Coquery-Vidrovitch \& Moniot [1993];Ki-Zerbo [1978]

Coquery-Vidrovitch \& Moniot [1993];Ki-Zerbo [1978]; Curtin [1978]

Ki-Zerbo [1978]; Curtin [1978]

Ki-Zerbo [1978]; Curtin [1978]

Coquery-Vidrovitch \& Moniot [1993];Ki-Zerbo [1978]; Curtin [1978]

Coquery-Vidrovitch \& Moniot [1993];Ki-Zerbo [1978]; Curtin [1978]

Coquery-Vidrovitch \& Moniot [1993];Ki-Zerbo [1978]; Curtin [1978]

Coquery-Vidrovitch \& Moniot [1993];Ki-Zerbo [1978]; Curtin [1978]

Coquery-Vidrovitch \& Moniot [1993];Ki-Zerbo [1978]; Curtin [1978]

Coquery-Vidrovitch \& Moniot [1993];Ki-Zerbo [1978]; Curtin [1978]

Ki-Zerbo [1978]

Coquery-Vidrovitch \& Moniot [1993];Ki-Zerbo [1978]; Curtin [1978]

Coquery-Vidrovitch \& Moniot [1993];Ki-Zerbo [1978]; Curtin [1978]

Coquery-Vidrovitch \& Moniot [1993];Ki-Zerbo [1978]; Curtin [1978]

Bouche [1991]; Coquery-Vidrovitch \& Moniot [1993];Ki-Zerbo [1978]; Curtin [1978]

Bouche [1991]; Coquery-Vidrovitch \& Moniot [1993];Ki-Zerbo [1978]; Curtin [1978]

Bouche [1991]; Coquery-Vidrovitch \& Moniot [1993];Ki-Zerbo [1978]; Curtin [1978]

Bouche [1991]; Coquery-Vidrovitch \& Moniot [1993];Ki-Zerbo [1978]; Curtin [1978]

Coquery-Vidrovitch \& Moniot [1993];Ki-Zerbo [1978]; Curtin [1978]

Coquery-Vidrovitch \& Moniot [1993];Ki-Zerbo [1978]; Curtin [1978]

Bouche [1991]; Coquery-Vidrovitch \& Moniot [1993];Ki-Zerbo [1978]; Curtin [1978]

Bouche [1991]; Coquery-Vidrovitch \& Moniot [1993];Ki-Zerbo [1978]; Curtin [1978]

Bouche [1991]; Coquery-Vidrovitch \& Moniot [1993];Ki-Zerbo [1978]; Curtin [1978]

Coquery-Vidrovitch \& Moniot [1993];Ki-Zerbo [1978]; Curtin [1978] 
Map 1: Territorial organization of the French West Africa (1925): colonies and districts

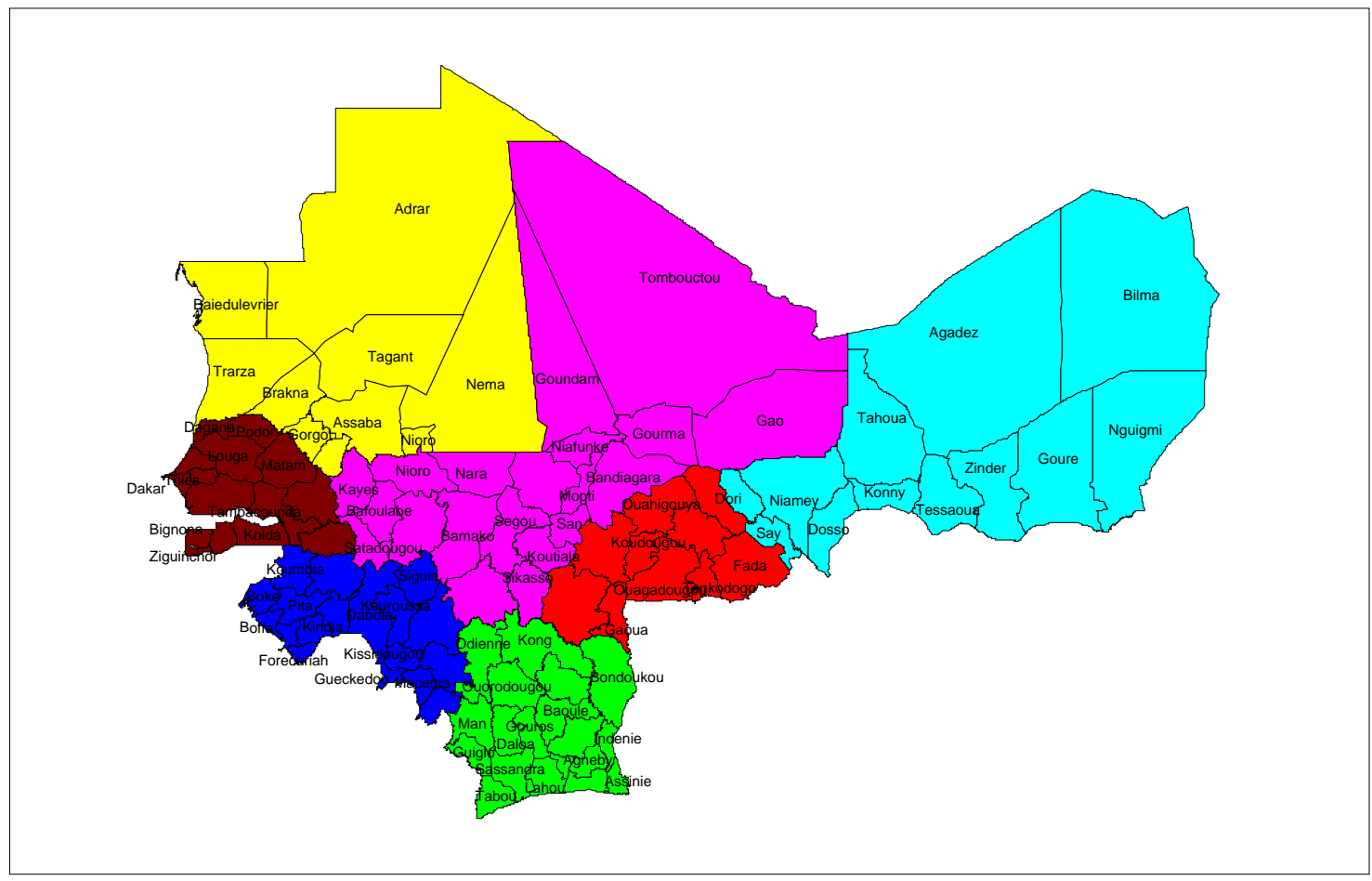

Map 2: Districts population density in 1910

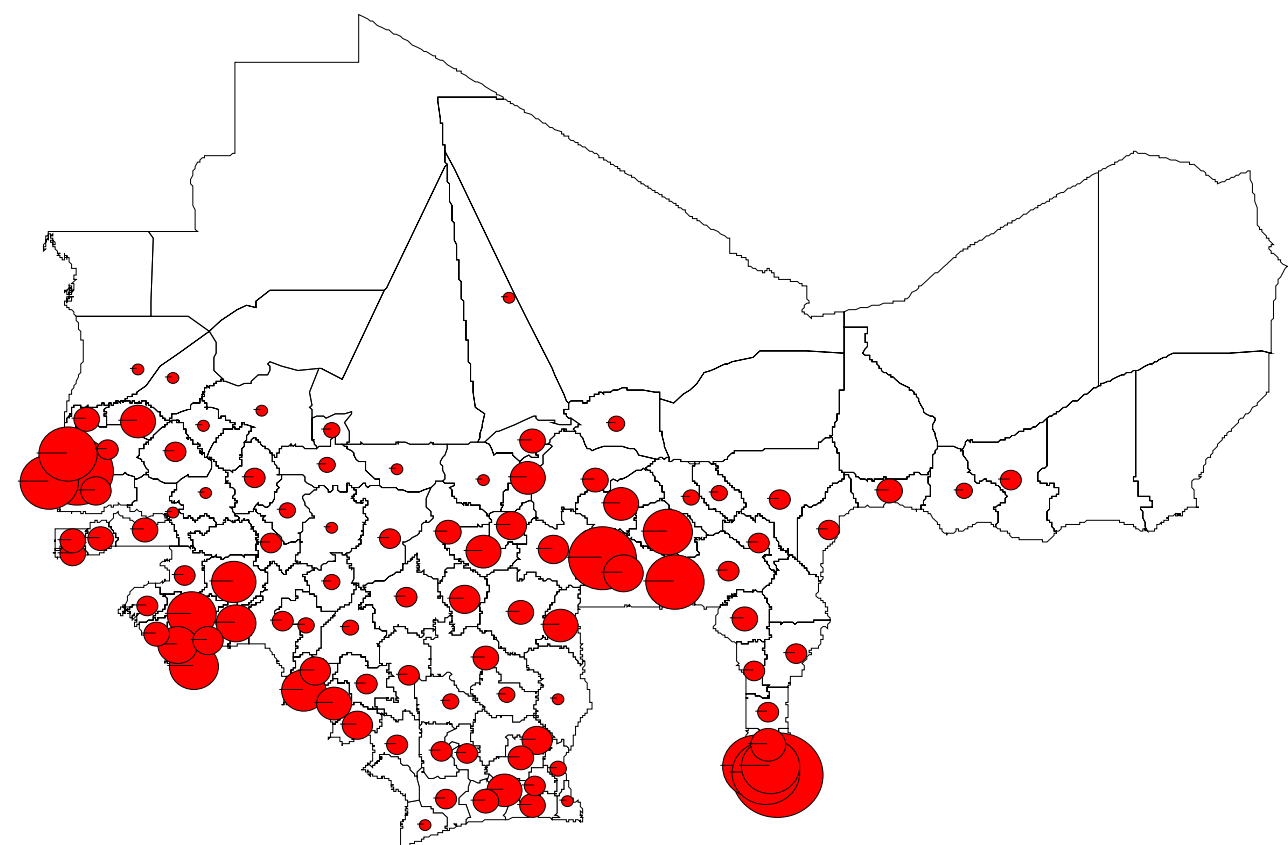

Source: Author's computations based on colonial censuses, Archives Nationales, Paris. 
Map 3: Hostility towards colonial power as measured by H3: average annual number of severe events expressing hostility over 1906-1920

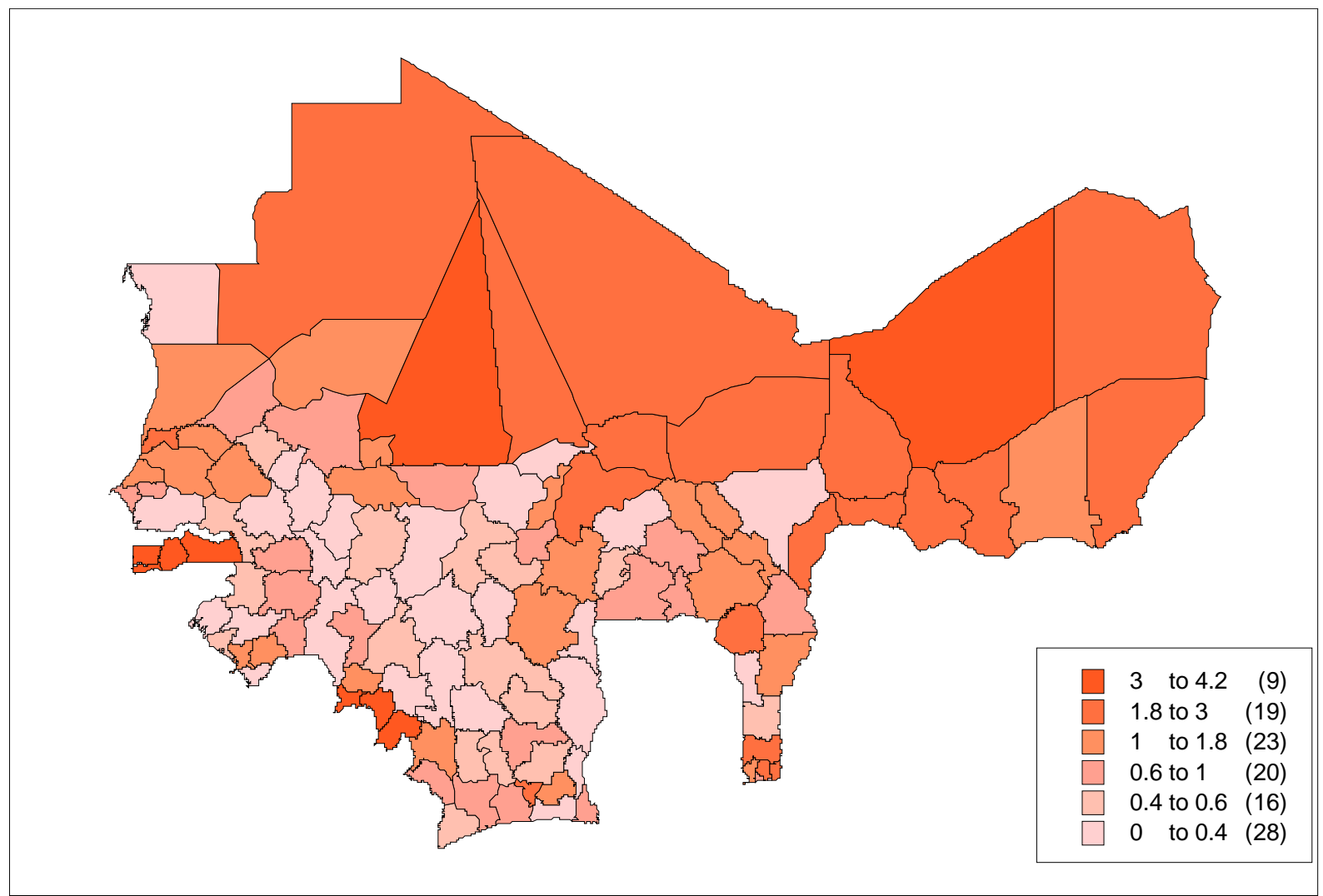

Source: Author's computations based on colonial annual political reports over 1906-1920 
Table 1: Summary statistics on districts

\begin{tabular}{|c|c|c|c|c|c|}
\hline Variable & Mean & Stand. Dev. & Min & Max & Nb Obs \\
\hline \multicolumn{6}{|l|}{ Current performances } \\
\hline Literacy rate (more than 15-year old) & 21.64 & 15.78 & 0.20 & 68.63 & 109 \\
\hline At least one year in primary school (>6-year old) & 18.63 & 11.62 & 2.03 & 70.54 & 109 \\
\hline At least one year in secundary school (>12-year old) & 8.05 & 6.82 & 0 & 41.21 & 109 \\
\hline Having access to a private water tap & 11.72 & 15.88 & 0 & 92.92 & 109 \\
\hline Connected to electricity & 13.66 & 17.86 & 0 & 87.51 & 109 \\
\hline Using a modern combustible for cooking & 22.40 & 30.67 & 0 & 99.99 & 109 \\
\hline Prop. of people having a house with a solid roof & 4.07 & 9.00 & 0 & 59.55 & 109 \\
\hline Prop. of people having a house with solid walls & 22.31 & 22.47 & 0 & 84.11 & 109 \\
\hline Stunting rate (less than 5 -year old children) & 36.88 & 12.25 & 7.14 & 85.71 & 89 \\
\hline \multicolumn{6}{|c|}{ Source: National Households Surveys around 1995 in former French West African colonies } \\
\hline \multicolumn{6}{|l|}{ Colonial period } \\
\hline Number of European settlers per 1000 hbt in 1910 & 1.25 & 3.73 & 0 & 30.64 & 110 \\
\hline Number of European settlers per 1000 hbt in 1925 & 2.73 & 12.32 & 0.03 & 113.75 & 110 \\
\hline Occurrence rate of events expressing hostility $(\mathrm{H} 1)$ & 0.49 & 0.30 & 0 & 1 & 110 \\
\hline Occurrence rate of severe events expressing hostility $(\mathrm{H} 2)$ & 0.43 & 0.29 & 0 & 1 & 110 \\
\hline Average annual number of severe events expressing hostility (H3) & 1.03 & 0.99 & 0 & 4.20 & 110 \\
\hline Local chiefs wages (in million francs) & $4,067.00$ & $8,253.00$ & 0 & $43,463.00$ & 110 \\
\hline Teachers per 1,000 inhabitants over 1910-1928 & 5.40 & 10.70 & 0.19 & 100.50 & 110 \\
\hline Doctors per 1,000 inhabitants over 1910-1928 & 9.79 & 21.90 & 0 & 182.50 & 110 \\
\hline Public works per km2 over $1910-1928$ & 5.42 & 24.09 & 0.004 & 222.90 & 110 \\
\hline \multicolumn{6}{|c|}{ Source: Colonial censuses and colonial annual political reports, Archives Nationales, Paris, France } \\
\hline \multicolumn{6}{|l|}{ Precolonial period } \\
\hline Population density in 1910 & 8.50 & 15.20 & 0.01 & 132.49 & 110 \\
\hline Desert-edge area dummy & 0.14 & 0.34 & 0 & 1 & 110 \\
\hline Trade counter dummy & 0.06 & 0.25 & 0 & 1 & 110 \\
\hline Pre-colonial kingdom dummy & 0.49 & 0.50 & 0 & 1 & 110 \\
\hline Amorphous area dummy & 0.12 & 0.32 & 0 & 1 & 110 \\
\hline \multicolumn{6}{|l|}{ Source: cf. Appendix1 } \\
\hline \multicolumn{6}{|l|}{ Geographical characteristics } \\
\hline Altitude (feets) & 799.42 & 583.51 & 0 & 3,044 & 110 \\
\hline Latitude & 11.83 & 3.73 & 4.77 & 20.97 & 110 \\
\hline Longitude & -5.82 & 7.00 & -17.06 & 12.92 & 110 \\
\hline Annual rainfalls average over $1915-1975(\mathrm{~mm})$ & $1,063.66$ & 683.63 & 17 & 3,248 & 110 \\
\hline Coastal dummy & 0.19 & 0.39 & 0 & 1 & 110 \\
\hline River dummy & 0.66 & 0.47 & 0 & 1 & 110 \\
\hline
\end{tabular}

Statistics are all calculated at the district level 
Table 2: Pre-colonial population density through different groups

(1)

Pre-colonial Kingdoms

(2)

Others

(1) - (2)

\begin{tabular}{cccc}
\hline 1910 Population density & 11,1 & 6 & $5,1^{*}$ \\
Obs number & 54 & 56 & $(2,8)$ \\
\hline & & & \\
& $(3)$ & $(4)$ & $(3)-(4)$ \\
\hline 1910 Population density & 0,55 & Others & $-9,2^{\star \star}$ \\
Obs number & 15 & 9,75 & $(4,15)$ \\
\hline & & 95 & \\
1910 Population density & $(5)$ & & $(6)$ \\
Obs number & 35,7 & 0 Others & $(5)-(6)$ \\
\hline
\end{tabular}

*** significant at the $1 \%$ level, ** significant at the $5 \%$ level, * significant at the $10 \%$ level.

This table reports mean of population density for different groups. For instance, the population

density of districts that belonged to a pre-colonial kingdoms was on average 11.1 inhabitants per km2,

whereas it was on average 6 for the other districts. The last column reports the average difference.

Standard errors are in parentheses. 
Table 3: The dissuasive impact of hostility and the attractive impact of pre-colonial economic prosperity on European settlement

\begin{tabular}{|c|c|c|}
\hline \multicolumn{3}{|c|}{ Dependent variable: Europeans per 1000 hbts in 1925} \\
\hline Independant variables & Coefficient & Standard error \\
\hline \multicolumn{3}{|c|}{ Panel A : Main effect of hostility and precolonial prosperity } \\
\hline Hostility (H3) & $-1,07^{\star \star \star}$ & $(0.34)$ \\
\hline Population density in 1910 & 0,014 & $(0.022)$ \\
\hline Desertic area dummy & $2.39 * \star$ & (1.18) \\
\hline Trade counter dummy & $5.53^{\star \star \star}$ & (1.58) \\
\hline $\mathrm{Nb}$ Obs & \multicolumn{2}{|c|}{110} \\
\hline R2 & \multicolumn{2}{|c|}{0.40} \\
\hline Pre-colonial political statuses & \multicolumn{2}{|c|}{ YES } \\
\hline Geographical controls & \multicolumn{2}{|c|}{ YES } \\
\hline
\end{tabular}

Panel B : Adding crossed-variables effects

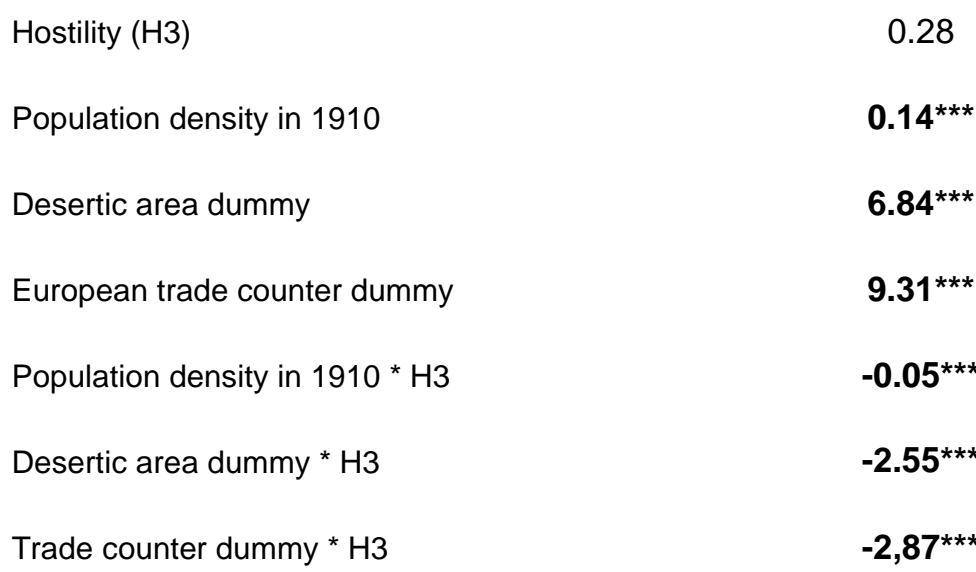

$\mathrm{Nb}$ Obs

R2 0.56

Pre-colonial political statuses $\quad$ YES

Geographical controls $\quad$ YES

*** significant at the $1 \%$ level, ** $5 \%$ level, * $10 \%$ level, $+15 \%$ level.

Each cell represents the coefficient from an OLS regression of the dependent variable on the independent variable.

Pre-colonial political statuses are kingdoms and amorphous areas.

Geographical controls are: average annual precipitations over 1910-1970, altitude,

longitude, latitude, navigable river dummy and coast dummy. 
Table 4: Causality beyond the correlation between hostility and European settlement

Dependent variable: Europeans per 1,000 hbts in...

\begin{tabular}{|c|c|c|c|c|}
\hline \multirow[b]{2}{*}{ Independant variables } & \multicolumn{2}{|c|}{$\begin{array}{c}(1) \\
1925\end{array}$} & \multicolumn{2}{|c|}{$\begin{array}{c}(2) \\
1950\end{array}$} \\
\hline & Coefficient & Standard error & Coefficient & Standard error \\
\hline \multicolumn{5}{|c|}{ Panel $A$ : Using $H 1$ as a measure of hostility } \\
\hline Hostility (H1) over period $t-1$ & $-0.60^{\star *}$ & $(0.24)$ & $-1.93^{*}$ & $(1.2)$ \\
\hline Europeans per $1,000 \mathrm{hbts}$ in time $t-1$ & $1.4^{\star \star \star}$ & $(0.05)$ & $2.7^{\star \star \star}$ & $(0.06)$ \\
\hline $\mathrm{Nb}$ Obs & \multicolumn{2}{|c|}{110} & \multicolumn{2}{|c|}{99} \\
\hline R2 & \multicolumn{2}{|c|}{0.88} & \multicolumn{2}{|c|}{0.95} \\
\hline
\end{tabular}

Panel B : Using H2 as a measure of hostility

\begin{tabular}{|c|c|c|c|c|}
\hline Hostility (H2) over period $t-1$ & $-0.48^{* *}$ & $(0.25)$ & $-2.8^{* *}$ & (1.3) \\
\hline Europeans per 1,000 hbts in time $t-1$ & $1.4^{\star \star \star}$ & $(0.05)$ & $2.7^{\star \star \star}$ & $(0.06)$ \\
\hline $\mathrm{Nb}$ Obs & \multicolumn{2}{|c|}{110} & \multicolumn{2}{|c|}{99} \\
\hline R2 & \multicolumn{2}{|c|}{0.88} & \multicolumn{2}{|c|}{0.95} \\
\hline
\end{tabular}

Panel C : Using $H 3$ as a measure of hostility

\begin{tabular}{|c|c|c|c|c|}
\hline Hostility $(\mathrm{H} 3)$ over period $t-1$ & -0.09 & $(0.07)$ & -0.9 & $(0.7)$ \\
\hline Europeans per 1,000 hbts in time $t-1$ & $1.4^{\star \star \star}$ & $(0.05)$ & $2.7^{\star \star \star}$ & $(0.06)$ \\
\hline $\mathrm{Nb}$ Obs & \multicolumn{2}{|c|}{110} & \multicolumn{2}{|c|}{99} \\
\hline $\mathrm{R} 2$ & \multicolumn{2}{|c|}{0.87} & \multicolumn{2}{|c|}{0.95} \\
\hline
\end{tabular}

*** significant at the $1 \%$ level, ** $5 \%$ level, * $10 \%$ level, $+15 \%$ level.

Each cell represents the coefficient from an OLS regression of the dependent variable

on the independent variable.

The number of Europeans per 1,000 hbts in time $t-1$ is the number of Europeans per 1,000 hbts in 1910 in regression (1) and the number of Europeans per 1,000 hbts in 1925 in regression (2).

The number of observations is 99 in regression (2) because data on Europeans in 1950 is missing for Mauritanian districts and for Kouroussa, Macenta and Nema.

$\mathrm{H} 1$ is the occurrence rate of events expressing hostility

$\mathrm{H} 2$ is the occurrence rate of only severe events expressing hostility

$\mathrm{H} 3$ is the average annual number of severe events expressing hostility

For each measure of hostility, period $t-1$ is 1906-1920 in regression (1) and 1920-1940 in regression (2) 
Table 5: The impact of European settlement on current outcomes: OLS and IV Estimates

\begin{tabular}{|c|c|c|c|c|c|c|c|c|c|}
\hline \multirow[b]{2}{*}{ Independant variables } & \multicolumn{9}{|c|}{ Dependent variable: district performance rate (in percentage points) with respect to... } \\
\hline & $\begin{array}{c}(1) \\
\text { Literacy }\end{array}$ & $\begin{array}{c}\text { (2) } \\
\text { Primary } \\
\text { School } \\
\end{array}$ & $\begin{array}{c}\text { (3) } \\
\text { Second. } \\
\text { School }\end{array}$ & (4) & $\begin{array}{c}\text { (5) } \\
\text { Electricity }\end{array}$ & $\begin{array}{c}\text { (6) } \\
\text { Modern } \\
\text { Combustible }\end{array}$ & $\begin{array}{c}\text { (7) } \\
\text { Wall } \\
\text { Solidity }\end{array}$ & $\begin{array}{c}\text { (8) } \\
\text { Roof } \\
\text { Solidity }\end{array}$ & $\begin{array}{c}\text { (9) } \\
\text { Stunting }\end{array}$ \\
\hline \multicolumn{10}{|c|}{ Panel A: OLS Estimates } \\
\hline Europeans per 1 ooo hbts in 1925 & $\begin{array}{c}1.01^{\star \star \star *} \\
(0.23)\end{array}$ & $\begin{array}{c}1.00^{* \star *} \\
(0.16)\end{array}$ & $\begin{array}{c}0.69^{\star \star \star} \\
(0.08)\end{array}$ & $\begin{array}{c}1.74^{\star \star \star *} \\
(0.20)\end{array}$ & $\begin{array}{c}2.03^{\star \star *} \\
(0.21)\end{array}$ & $\begin{array}{c}1.85^{\star \star \star *} \\
(0.47)\end{array}$ & $\begin{array}{c}1.48^{\star \star *} \\
(0.34)\end{array}$ & $\begin{array}{c}0.72^{\star \star \star} \\
(0.13)\end{array}$ & $\begin{array}{c}-1.49^{* *} \\
(0.66)\end{array}$ \\
\hline $\begin{array}{l}\text { R-squared } \\
\mathrm{Nb} \text { Obs }\end{array}$ & $\begin{array}{l}0.17 \\
109\end{array}$ & $\begin{array}{l}0.26 \\
109\end{array}$ & $\begin{array}{l}0.36 \\
109\end{array}$ & $\begin{array}{l}0.42 \\
109\end{array}$ & $\begin{array}{l}0.45 \\
109\end{array}$ & $\begin{array}{c}0.13 \\
109\end{array}$ & $\begin{array}{l}0.15 \\
109\end{array}$ & $\begin{array}{l}0.22 \\
109\end{array}$ & $\begin{array}{c}0.06 \\
89\end{array}$ \\
\hline \multicolumn{10}{|c|}{ Panel B : OLS Estimates adding control variables } \\
\hline Europeans per 1 ooo hbts in 1925 & $\begin{array}{l}\mathbf{0 . 7 9} \mathbf{9}^{\star \star *} \\
(0.21)\end{array}$ & $\begin{array}{c}0.65^{\star \star \star} \\
(0.16)\end{array}$ & $\begin{array}{c}\mathbf{0 . 5 8} 8^{\star \star \star} \\
(0.08)\end{array}$ & $\begin{array}{c}1.25^{\star \star *} \\
(0.21)\end{array}$ & $\begin{array}{c}1.95^{\star \star \star *} \\
(0.21)\end{array}$ & $\begin{array}{c}1.22^{\star * *} \\
(0.48)\end{array}$ & $\begin{array}{c}1.08 * \star * \\
(0.31)\end{array}$ & $\begin{array}{c}\mathbf{0 . 6 0}(* \star 10 \\
(0.10)\end{array}$ & $\begin{array}{c}-1.85^{* *} \\
(0.93)\end{array}$ \\
\hline R-squared & 0.57 & 0.54 & 0.66 & 0.60 & 0.68 & 0.43 & 0.55 & 0.68 & 0.32 \\
\hline $\mathrm{Nb}$ Obs & 109 & 109 & 109 & 109 & 109 & 109 & 109 & 109 & 89 \\
\hline Pre-colonial prosperity controls & YES & YES & YES & YES & YES & YES & YES & YES & YES \\
\hline Pre-colonial political controls & YES & YES & YES & YES & YES & YES & YES & YES & YES \\
\hline Geographical controls & YES & YES & YES & YES & YES & YES & YES & YES & YES \\
\hline \multicolumn{10}{|c|}{ Panel C : IV Estimates } \\
\hline Europeans per 1 ooo hbts in 1925 & $\begin{array}{l}0.56^{*} \\
(0.32)\end{array}$ & $\begin{array}{l}0.52^{\star *} \\
(0.24)\end{array}$ & $\begin{array}{c}0.45^{\star \star *} \\
(0.14)\end{array}$ & $\begin{array}{c}1.76^{* \star *} \\
(0.34)\end{array}$ & $\begin{array}{c}1.31^{\star \star \star *} \\
(0.35)\end{array}$ & $\begin{array}{l}1.54^{\star *} \\
(0.79)\end{array}$ & $\begin{array}{l}1.19^{* *} \\
(0.52)\end{array}$ & $\begin{array}{c}\mathbf{0 . 4 8} * \star * \\
(0.17)\end{array}$ & $\begin{array}{c}-4.44^{\star *} \\
(2.10)\end{array}$ \\
\hline Centered R-squared & 0.62 & 0.63 & 0.66 & 0.59 & 0.67 & 0.44 & 0.55 & 0.68 & 0.25 \\
\hline Partial R-squared & 0.33 & 0.33 & 0.33 & 0.33 & 0.33 & 0.33 & 0.33 & 0.33 & 0.33 \\
\hline $\mathrm{Nb}$ Obs & 109 & 109 & 109 & 109 & 109 & 109 & 109 & 109 & 89 \\
\hline Included instruments & \multirow{2}{*}{\multicolumn{9}{|c|}{ 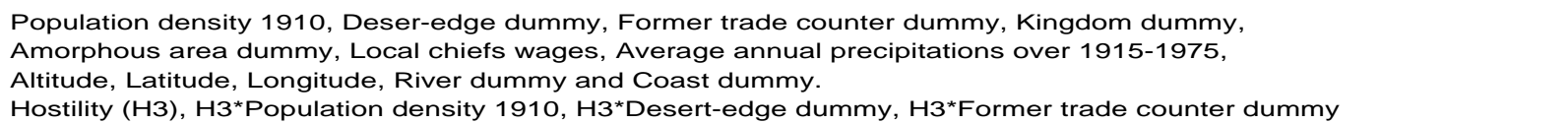 }} \\
\hline Excluded instruments & & & & & & & & & \\
\hline
\end{tabular}

*** significant at the $1 \%$ level, ** $5 \%$ level, * $10 \%$ level, $+15 \%$ level.

Each cell in panel A and panel B represents the coefficient from an OLS regression of the dependent variable on the independent variable.

Pre-colonial prosperity controls are: population density 1910, desert-edge dummy, former trade counter dummy

Pre-colonial political statuses are: kingdoms and amorphous areas dummies.

Geographical controls are: average annual precipitations over 1915-1975, altitude, longitude, latitude, river dummy and coast dummy.

Each cell in panel C represents the coefficient from a 2SLS regression of the dependent variable on the independent variable.

Instrumented variable is the number of Europeans per 1000 inhabitants in 1925 
Table 6: Do colonial public investments explain the positive influence of European settlement?

\begin{tabular}{|c|c|c|c|c|c|c|c|c|c|}
\hline \multirow[b]{2}{*}{ Independant variables } & \multicolumn{9}{|c|}{ Dependent variable: district performance rate with respect to... } \\
\hline & $\begin{array}{c}(1) \\
\text { Literacy } \\
\end{array}$ & $\begin{array}{c}(2) \\
\text { Primary } \\
\text { School } \\
\end{array}$ & $\begin{array}{c}(3) \\
\text { Second. } \\
\text { School }\end{array}$ & $\begin{array}{c}(4) \\
\text { Water } \\
\end{array}$ & $\begin{array}{c}(5) \\
\text { Electricity }\end{array}$ & $\begin{array}{c}6) \\
\text { Modern } \\
\text { Combustible } \\
\end{array}$ & $\begin{array}{c}(7) \\
\text { Wall } \\
\text { Solidity } \\
\end{array}$ & $\begin{array}{c}(8) \\
\text { Roof } \\
\text { Solidity } \\
\end{array}$ & $\begin{array}{c}\text { (9) } \\
\text { Stunting } \\
\end{array}$ \\
\hline Teachers per 100,000 hbts over $1910-1928$ & $\begin{array}{l}-0.30 \\
(0.25)\end{array}$ & $\begin{array}{l}\mathbf{0 . 3 1 * *} \\
(0.13)\end{array}$ & $\begin{array}{l}\mathbf{0 . 1 9 * * *} \\
(0.07)\end{array}$ & & & & & & \\
\hline Doctors per 100,000 hbts over $1910-1928$ & & & & & & & & & $\begin{array}{l}-0.45^{* *} \\
(0.20)\end{array}$ \\
\hline Public works per km² over $1910-1928$ & & & & $\begin{array}{l}\mathbf{0 . 4 1 * * *} \\
(0.14)\end{array}$ & $\begin{array}{l}\mathbf{0 . 3 6} \\
(0.13)\end{array}$ & $\begin{array}{l}\mathbf{0 . 5 0 ^ { * }} \\
(0.30)\end{array}$ & 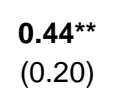 & $\begin{array}{l}-0.05 \\
(0.07)\end{array}$ & \\
\hline Europeans per 1,000 hbts in 1925 & $\begin{array}{c}1.2^{\text {** }} \\
(0.39)\end{array}$ & $\begin{array}{c}0.47 \\
(0.30)\end{array}$ & $\begin{array}{l}\mathbf{0 . 2 5 ^ { \star * }} \\
(0.11)\end{array}$ & $\begin{array}{l}\mathbf{0 . 6 8}^{*} \\
(0.39)\end{array}$ & $\begin{array}{c}1.68^{\star \star *} \\
(0.52)\end{array}$ & $\begin{array}{c}1.82 \\
(2.27)\end{array}$ & $\begin{array}{c}0.75^{\star \star *} \\
(0.20)\end{array}$ & $\begin{array}{c}0.95^{\star \star \star} \\
(0.30)\end{array}$ & $\begin{array}{l}-0.65 \\
(1.09)\end{array}$ \\
\hline $\mathrm{Nb}$ Obs & 109 & 109 & 109 & 109 & 109 & 109 & 109 & 109 & 89 \\
\hline $\begin{array}{l}\text { R2 } \\
\text { Pre-colonial prosperity controls }\end{array}$ & 0.58 & 0.54 & 0.67 & 0.63 & 0.68 & 0.44 & 0.55 & 0.72 & 0.35 \\
\hline Pre-colonial political statuses & YES & YES & YES & YES & YES & YES & NO & YES & YES \\
\hline Geographical controls & YES & YES & YES & YES & YES & YES & NO & YES & YES \\
\hline
\end{tabular}

*** significant at the $1 \%$ level, $* * 5 \%$ level, * $10 \%$ level, $+15 \%$ level.

Each cell represents the coefficient from an OLS regression of the dependent variable on the independent variable.

Pre-colonial prosperity controls are: population density 1910, desert-edge dummy, former trade counter dummy

Pre-colonial political statuses are kingdoms and amorphous areas.

Geographical controls are: average annual precipitations over 1910-1970, altitude, longitude, latitude, navigable river dummy and coast dummy 


\section{Table 7: Did prosperous pre-colonial areas fall behind?}

\begin{tabular}{|c|c|c|c|c|c|c|c|c|c|}
\hline Independant variables & Literacy & $\begin{array}{c}\text { Attended } \\
\text { Primary School }\end{array}$ & $\begin{array}{c}\text { Dep } \\
\text { Attended } \\
\text { Second. School }\end{array}$ & $\begin{array}{l}\text { ent variable: } \\
\text { Water tap }\end{array}$ & $\begin{array}{l}\text { serformance } \\
\text { Electricity }\end{array}$ & $\begin{array}{l}\text { ith respect to... } \\
\text { Modern } \\
\text { Combustible }\end{array}$ & Solid Wall & Solid Roof & Stunting \\
\hline \multicolumn{10}{|c|}{ Panel A : Precolonial prosperity variables } \\
\hline Population density in 1910 & 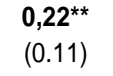 & $\begin{array}{c}\mathbf{0 . 2 6 ^ { * \star * }} \\
(0.07)\end{array}$ & $\begin{array}{l}0.07^{*} \\
(0.04)\end{array}$ & $\begin{array}{c}\mathbf{0 . 3 0}(\mathbf{* *} \\
(0.09)\end{array}$ & $\begin{array}{c}0.17 \\
(0.12)\end{array}$ & $\begin{array}{l}\mathbf{0 . 5 3 ^ { \star * }} \\
(0.21)\end{array}$ & $\begin{array}{l}0.003 \\
(0.16)\end{array}$ & $\begin{array}{c}0.09 \\
(0.06)\end{array}$ & $\begin{array}{c}0.12 \\
(0.19)\end{array}$ \\
\hline Desertic area dummy & $\begin{array}{l}8.4^{\star *} \\
(4.3)\end{array}$ & $\begin{array}{c}10.9^{* \star \star} \\
(2.8)\end{array}$ & $\begin{array}{c}0.42 \\
(1.72)\end{array}$ & $\begin{array}{c}9.75^{\star * *} \\
(3.8)\end{array}$ & $\begin{array}{c}3.5 \\
(4.6)\end{array}$ & $\begin{array}{c}3.66 \\
(8.34)\end{array}$ & $\begin{array}{l}-0.33 \\
(6.49)\end{array}$ & $\begin{array}{l}6.44^{\star *} \\
(2.58)\end{array}$ & $\begin{array}{c}1 \\
(4.8)\end{array}$ \\
\hline Trade counter dummy & $\begin{array}{c}15.6^{* \star} \\
(6.5)\end{array}$ & $\begin{array}{c}13.2^{* * *} \\
(4.3)\end{array}$ & $\begin{array}{l}12^{* * *} \\
(2.6)\end{array}$ & $\begin{array}{c}25,7^{* * *} \\
(5.7)\end{array}$ & $\begin{array}{c}28.9^{* * *} \\
(7.03)\end{array}$ & $\begin{array}{l}25.8^{* \star} \\
(12.6)\end{array}$ & $\begin{array}{c}19.9^{* *} \\
(9.8)\end{array}$ & $\begin{array}{c}-1.82 \\
(3.9)\end{array}$ & $\begin{array}{l}-3.5 \\
(6.3)\end{array}$ \\
\hline $\mathrm{Nb}$ Obs & 109 & 109 & 109 & 109 & 109 & 109 & 109 & 109 & 89 \\
\hline R2 & 0.16 & 0.32 & 0.27 & 0.35 & 0.23 & 0.16 & 0.05 & 0.06 & 0.01 \\
\hline Pre-colonial political controls & NO & NO & NO & NO & NO & NO & NO & NO & NO \\
\hline Geographical controls & NO & NO & NO & $\mathrm{NO}$ & NO & $\mathrm{NO}$ & $\mathrm{NO}$ & NO & $\mathrm{NO}$ \\
\hline & & & Panel B : Adding & graphical anc & a controls & & & & \\
\hline Population density in 1910 & $\begin{array}{c}0.06 \\
(0.09)\end{array}$ & $\begin{array}{c}\mathbf{0 . 2 2 * * *} \\
(0.07)\end{array}$ & $\begin{array}{c}0.04 \\
(0.04)\end{array}$ & $\begin{array}{c}\mathbf{0 . 2 5} 5^{\star \star *} \\
(0.09)\end{array}$ & $\begin{array}{c}0.07 \\
(0.10)\end{array}$ & $\begin{array}{l}0.32^{*} \\
(0.19)\end{array}$ & $\begin{array}{l}-0.11 \\
(0.13)\end{array}$ & $\begin{array}{c}0.06 \\
(0.05)\end{array}$ & $\begin{array}{c}0.24 \\
(0.18)\end{array}$ \\
\hline Desertic area dummy & $\begin{array}{l}9.2^{* *} \\
(4.4)\end{array}$ & $\begin{array}{c}8.17^{\star *} \\
(3.4)\end{array}$ & $\begin{array}{l}\mathbf{5 . 2 * * *} \\
(1.96)\end{array}$ & $\begin{array}{c}12.33^{\star * *} \\
(4.7)\end{array}$ & $\begin{array}{l}12.1^{* *} \\
(5.22)\end{array}$ & $\begin{array}{c}15 \\
(9.6)\end{array}$ & $\begin{array}{c}17.33^{* * *} \\
(6.45)\end{array}$ & $\begin{array}{c}0.59 \\
(2.35)\end{array}$ & $\begin{array}{c}-13.09^{\star \star} \\
(5.54)\end{array}$ \\
\hline Trade counter dummy & $\begin{array}{l}-2.4 \\
(6.05)\end{array}$ & $\begin{array}{l}7.7^{*} \\
(4.6)\end{array}$ & $\begin{array}{c}5.93^{\star *} \\
(2.6)\end{array}$ & $\begin{array}{c}16.32^{\star \star *} \\
(6.45)\end{array}$ & $\begin{array}{l}11.3^{*} \\
(7.08)\end{array}$ & $\begin{array}{c}-4.32 \\
(13.05)\end{array}$ & $\begin{array}{c}-2 \\
(8.75)\end{array}$ & $\begin{array}{l}-7.24 \\
(6.9)\end{array}$ & $\begin{array}{l}-1.19 \\
(2.8)\end{array}$ \\
\hline $\mathrm{Nb}$ Obs & 109 & 109 & 109 & 109 & 109 & 109 & 109 & 109 & 89 \\
\hline R2 & 0.51 & 0.47 & 0.49 & 0.45 & 0.47 & 0.39 & 0.49 & 0.58 & 0.29 \\
\hline Pre-colonial political controls & YES & YES & YES & YES & YES & YES & YES & YES & YES \\
\hline Geographical controls & YES & YES & YES & YES & YES & YES & YES & YES & YES \\
\hline
\end{tabular}

${ }^{* * *}$ significant at the $1 \%$ level, ** $5 \%$ level, ${ }^{*} 10 \%$ level, $+15 \%$ level.

Each cell represents the coefficient from an OLS regression of the dependent variable

on the independent variable.

Pre-colonial political controls are: kingdom dummy and amorphous area dummy.

Geographical controls are: average annual precipitations over 1910-1970, altitude, longitude, latitude,

navigable river dummy and coast dummy. 


\section{Graph 1}

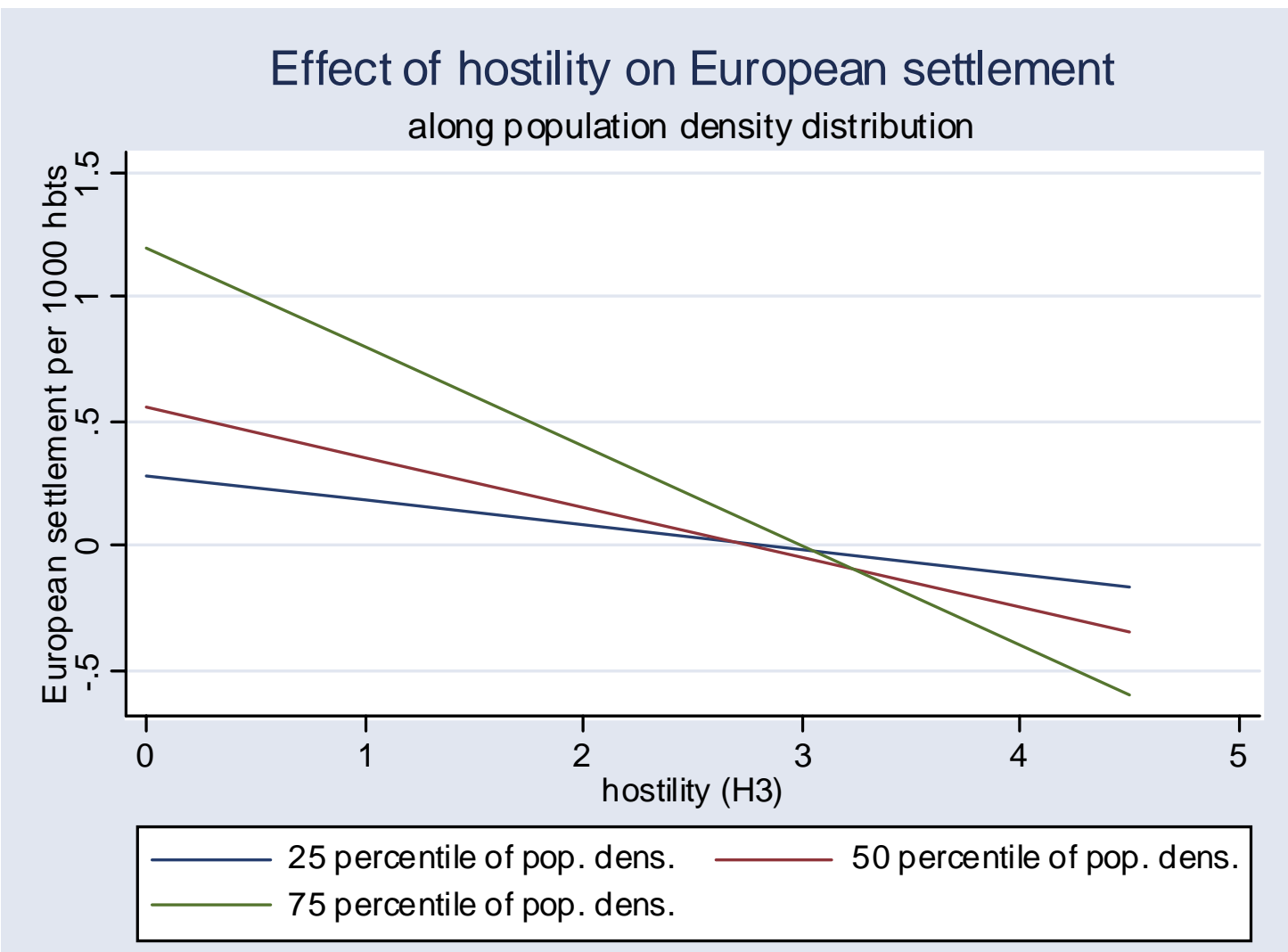

\section{Graph 2}

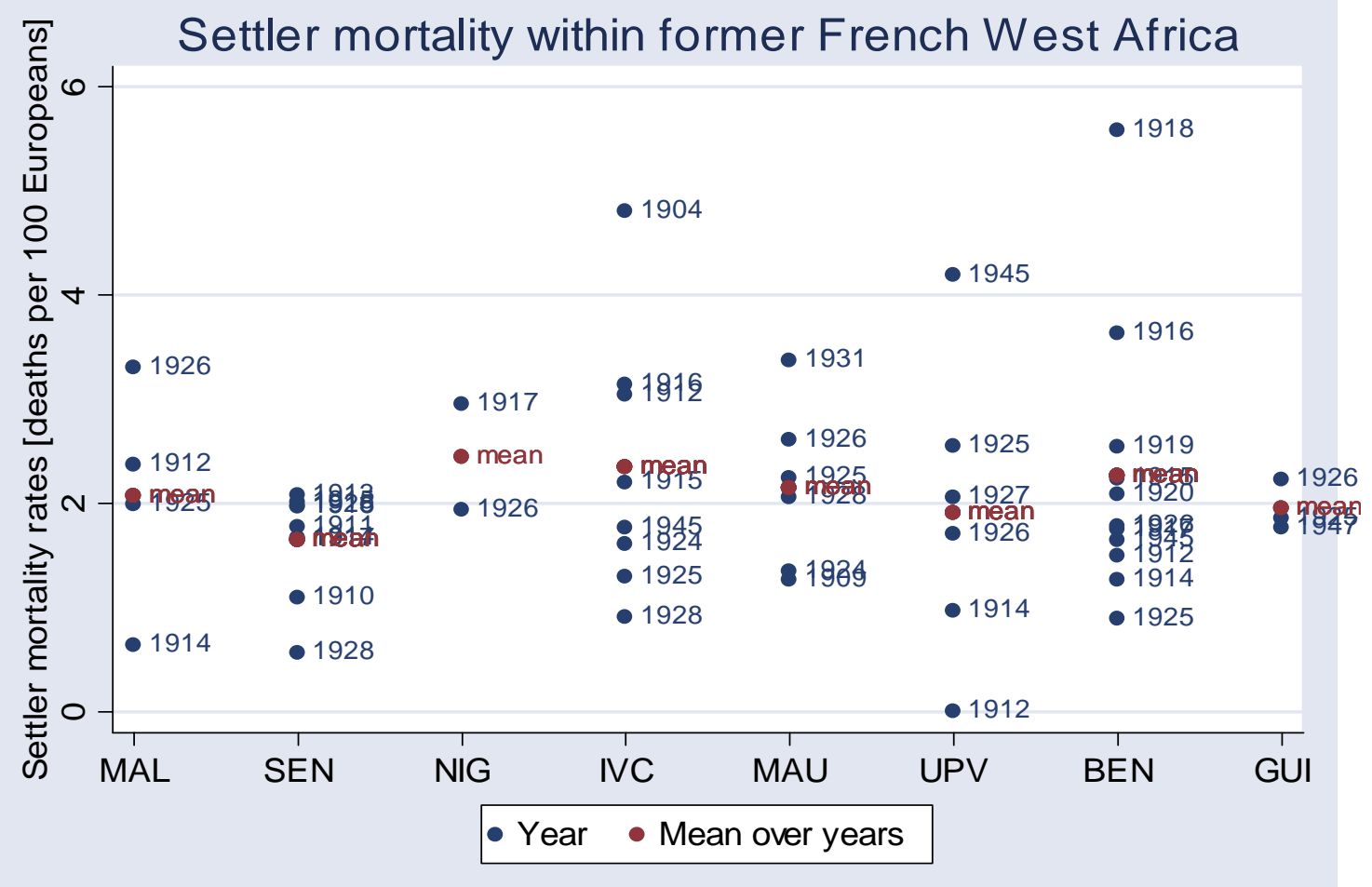




\section{Graph 3}

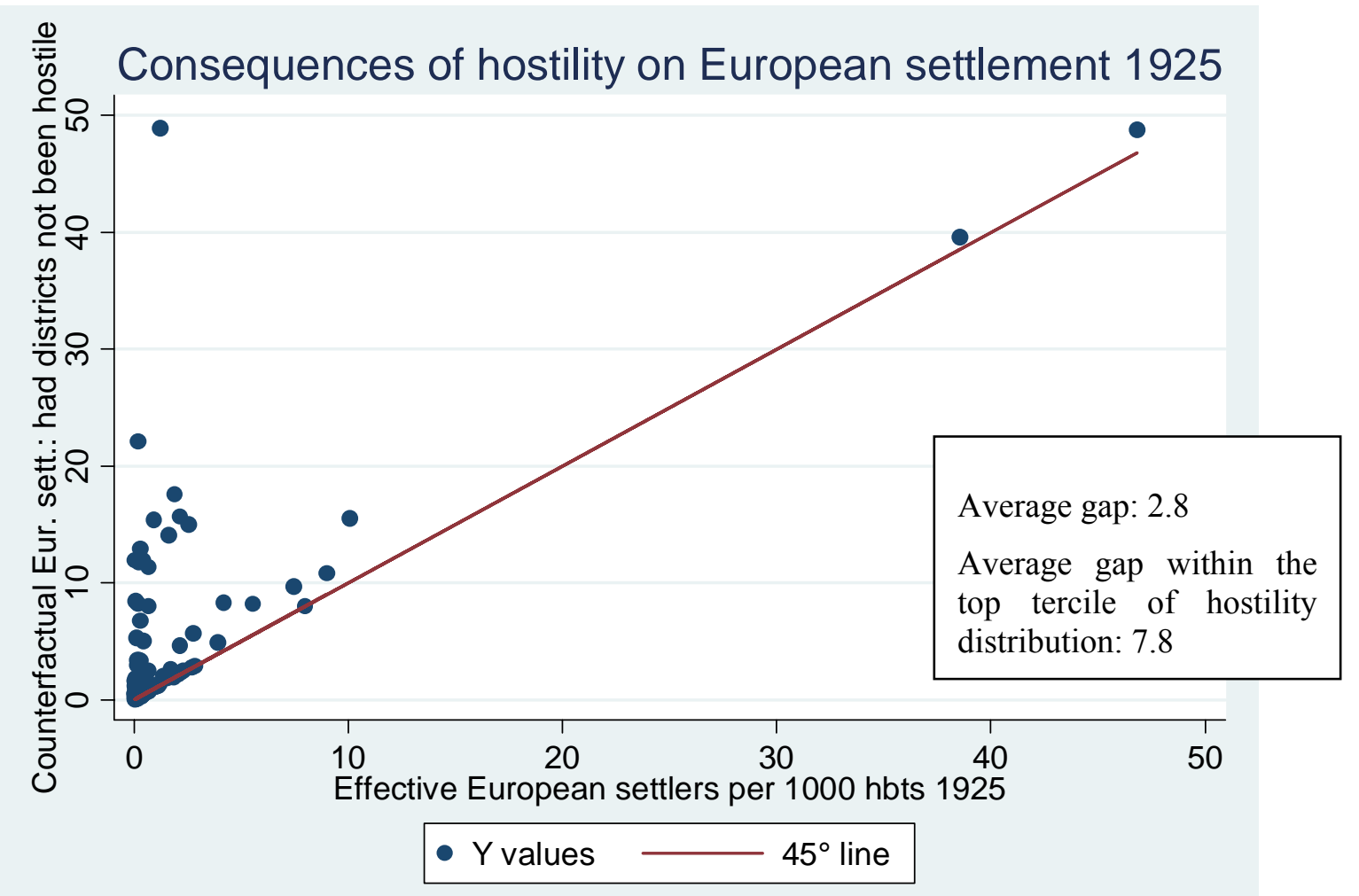

\section{Graph 4}

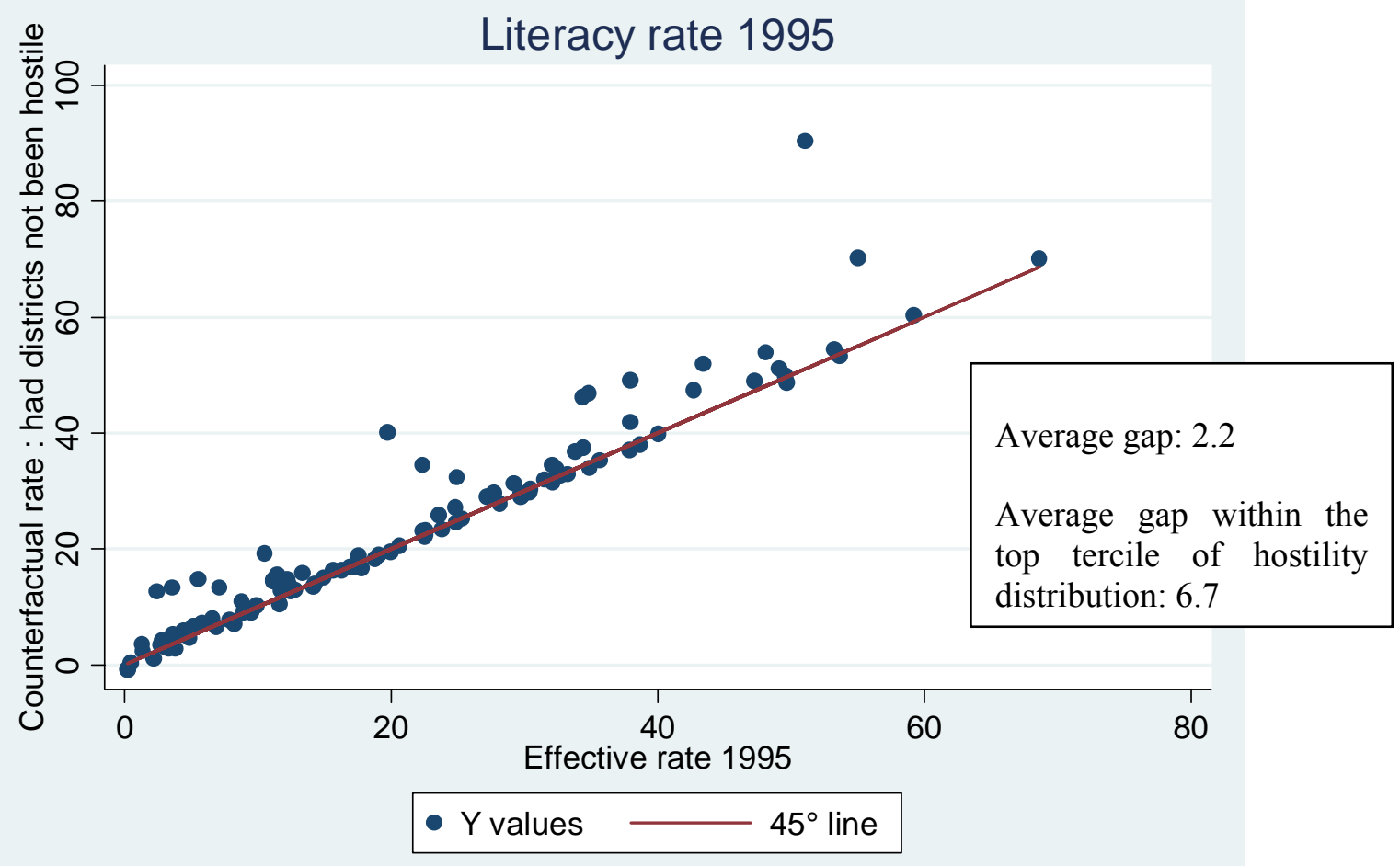




\section{Graph 5}

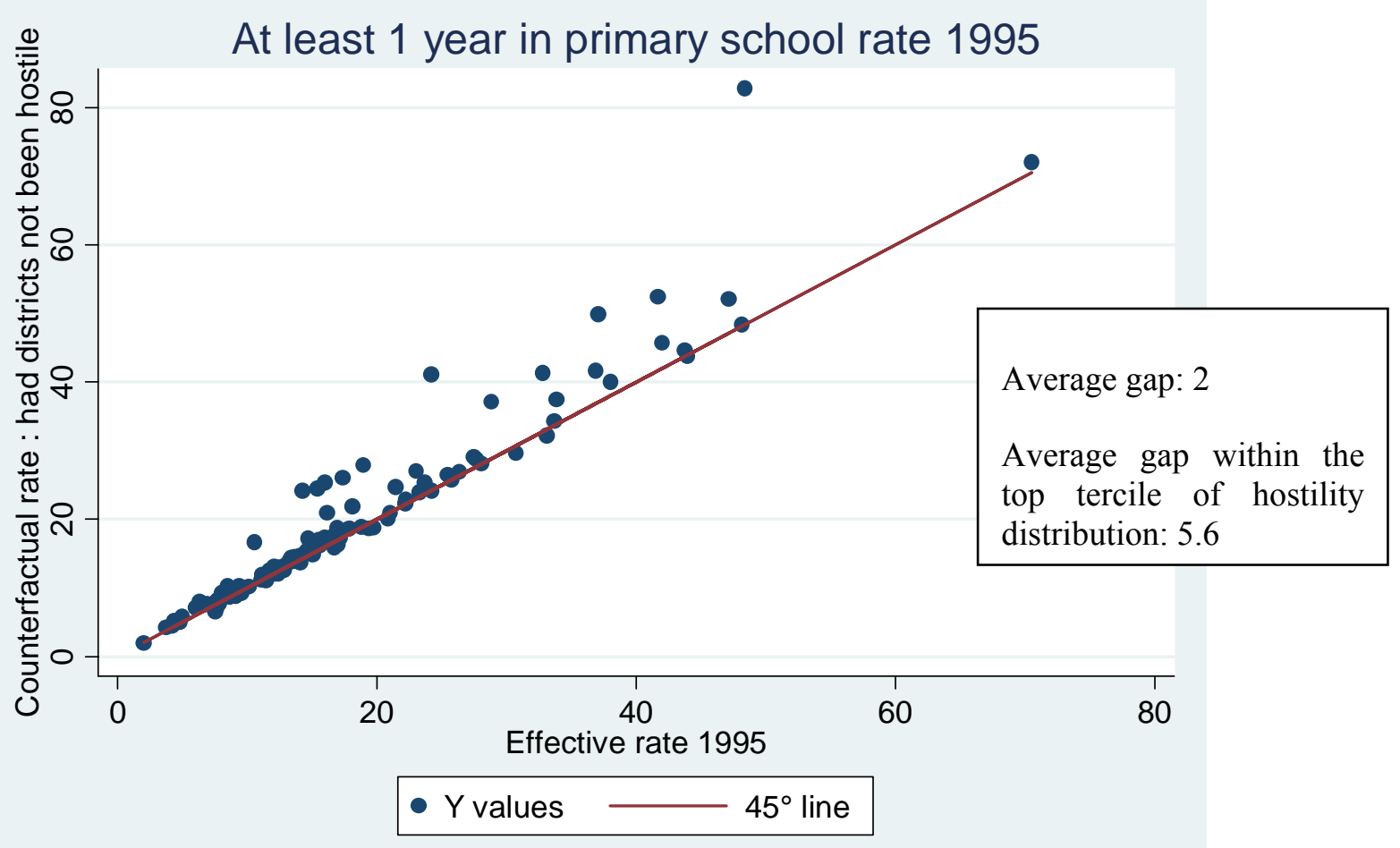

\section{Graph 6}

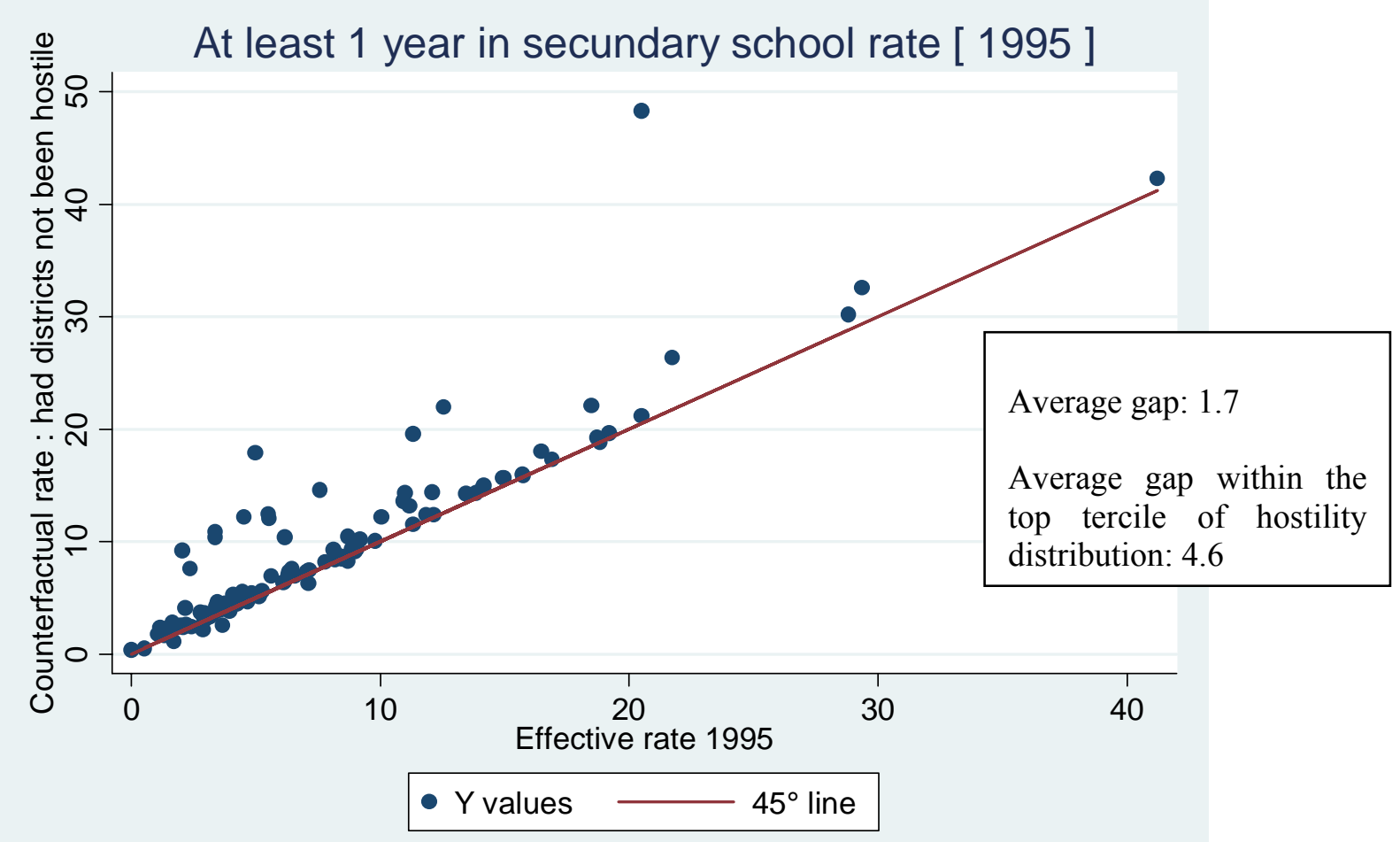




\section{Graph 7}

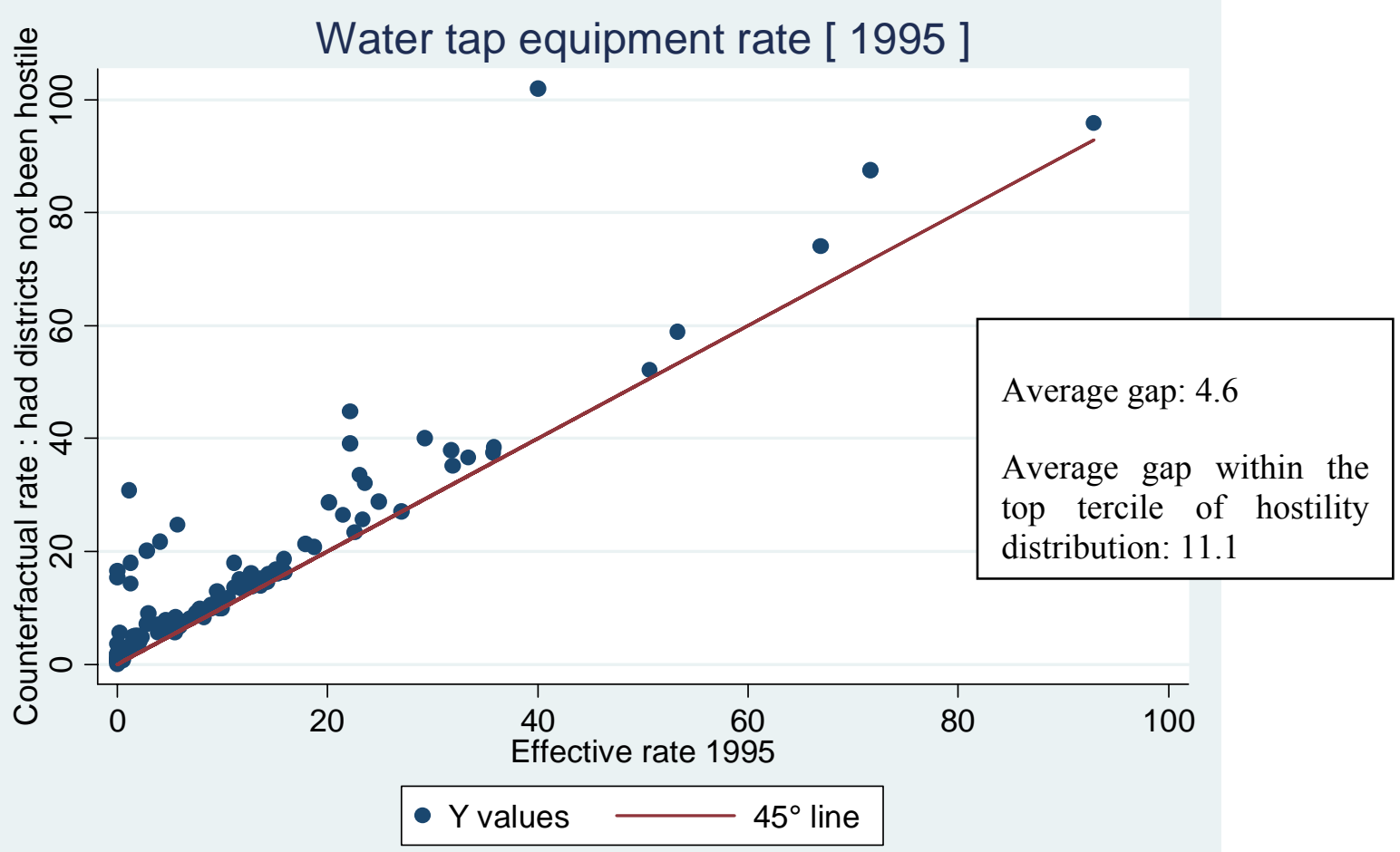

\section{Graph 8}

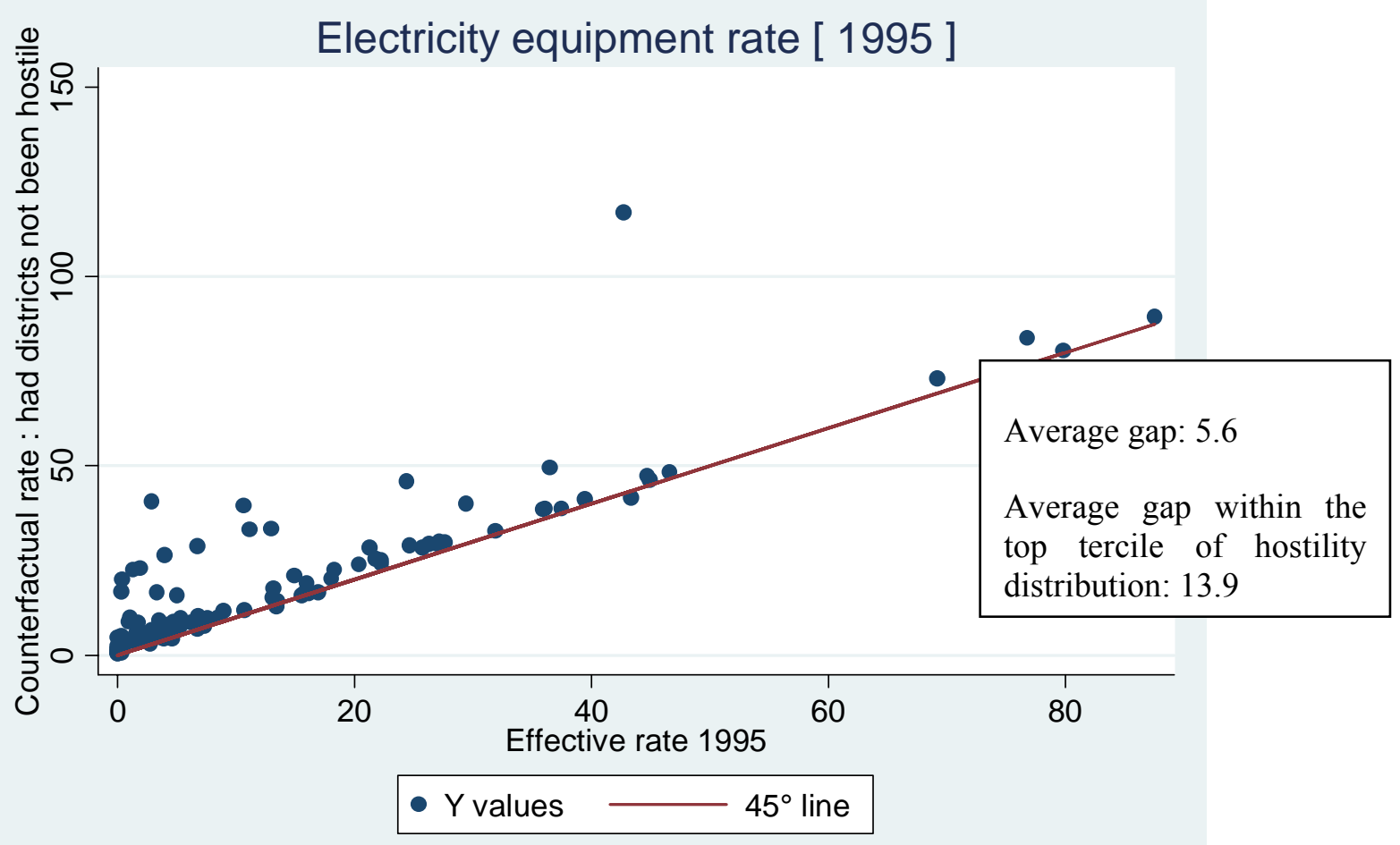




\section{Graph 9}

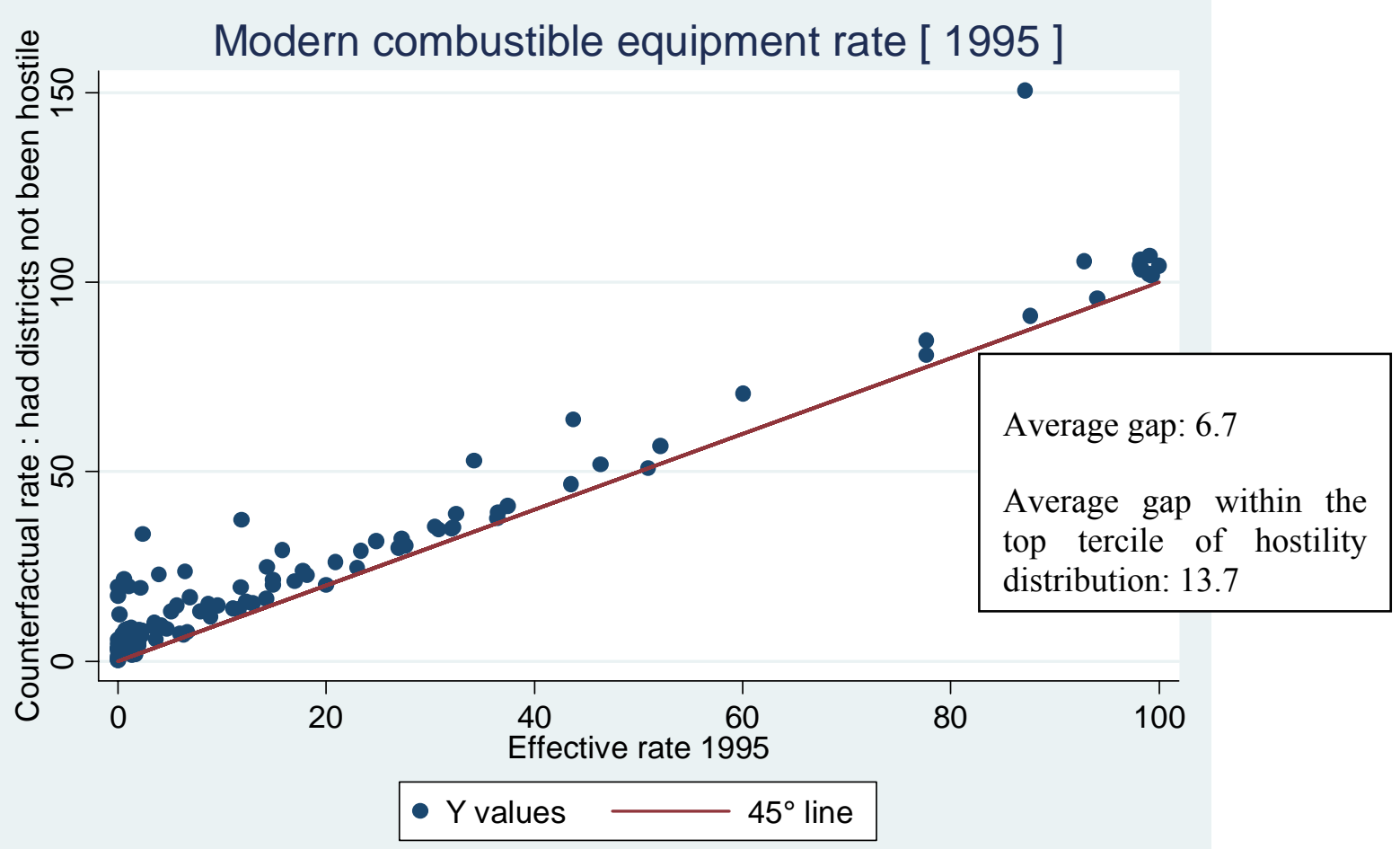

\section{Graph 10}

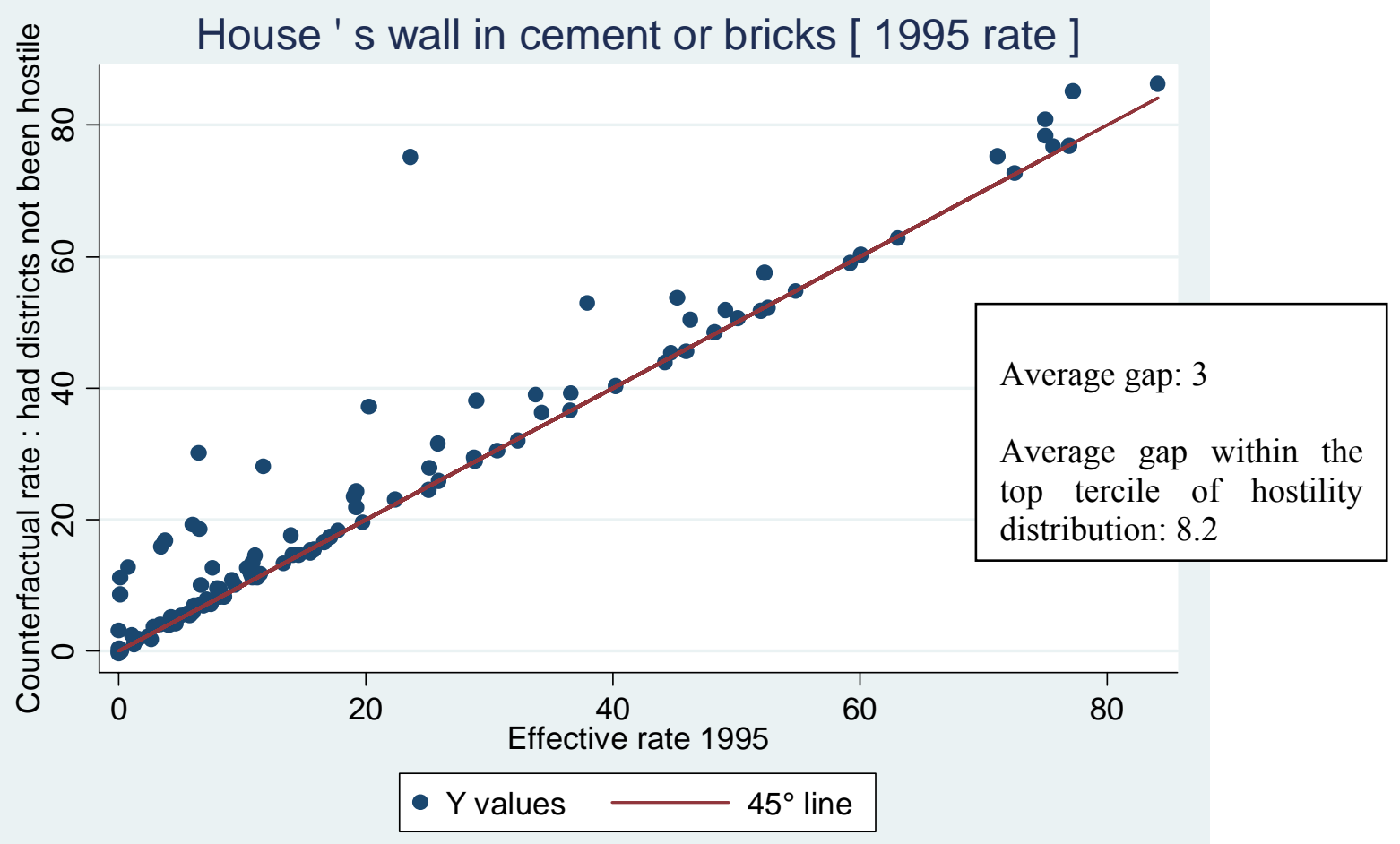




\section{Graph 11}

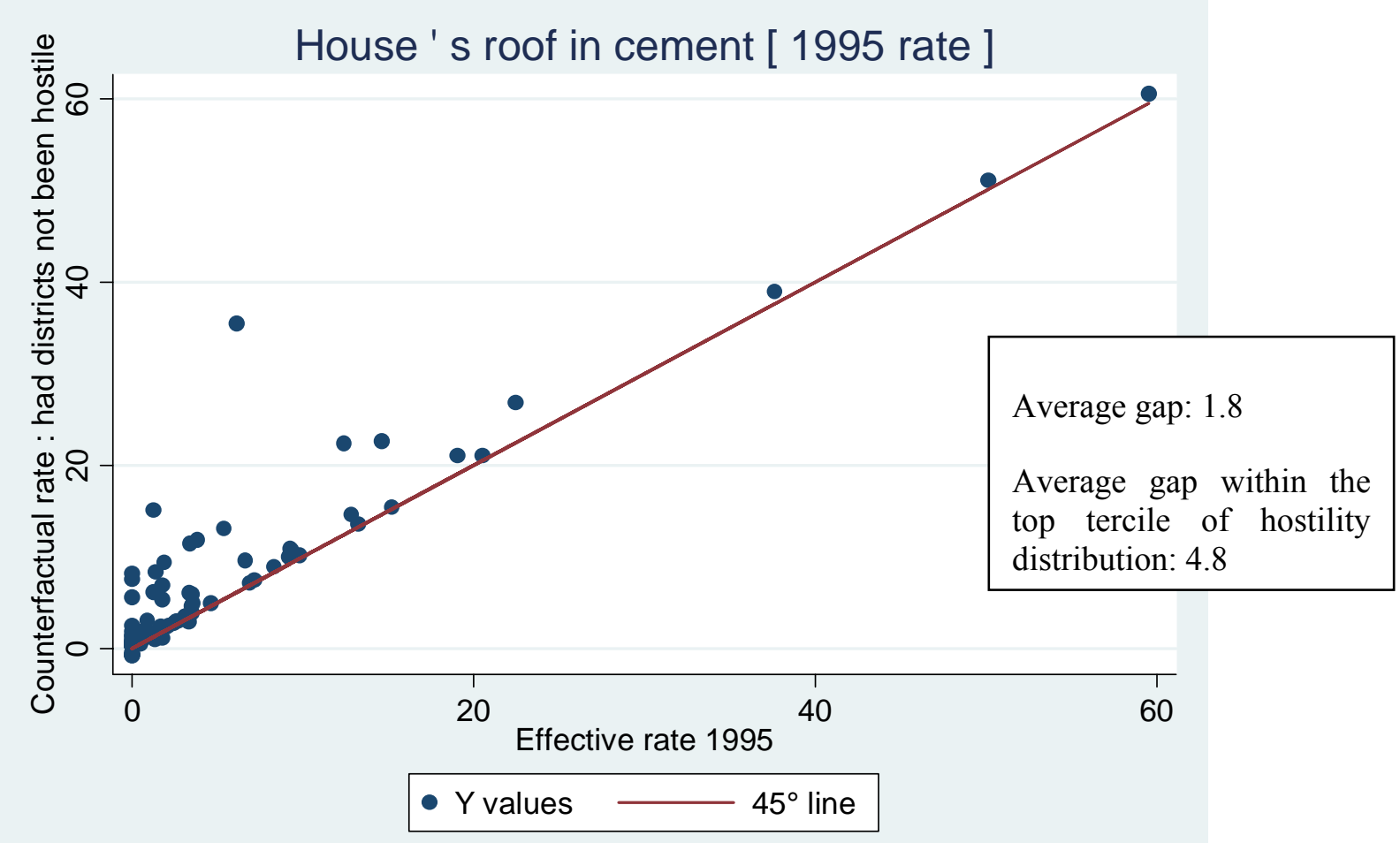

\section{Graph 12}

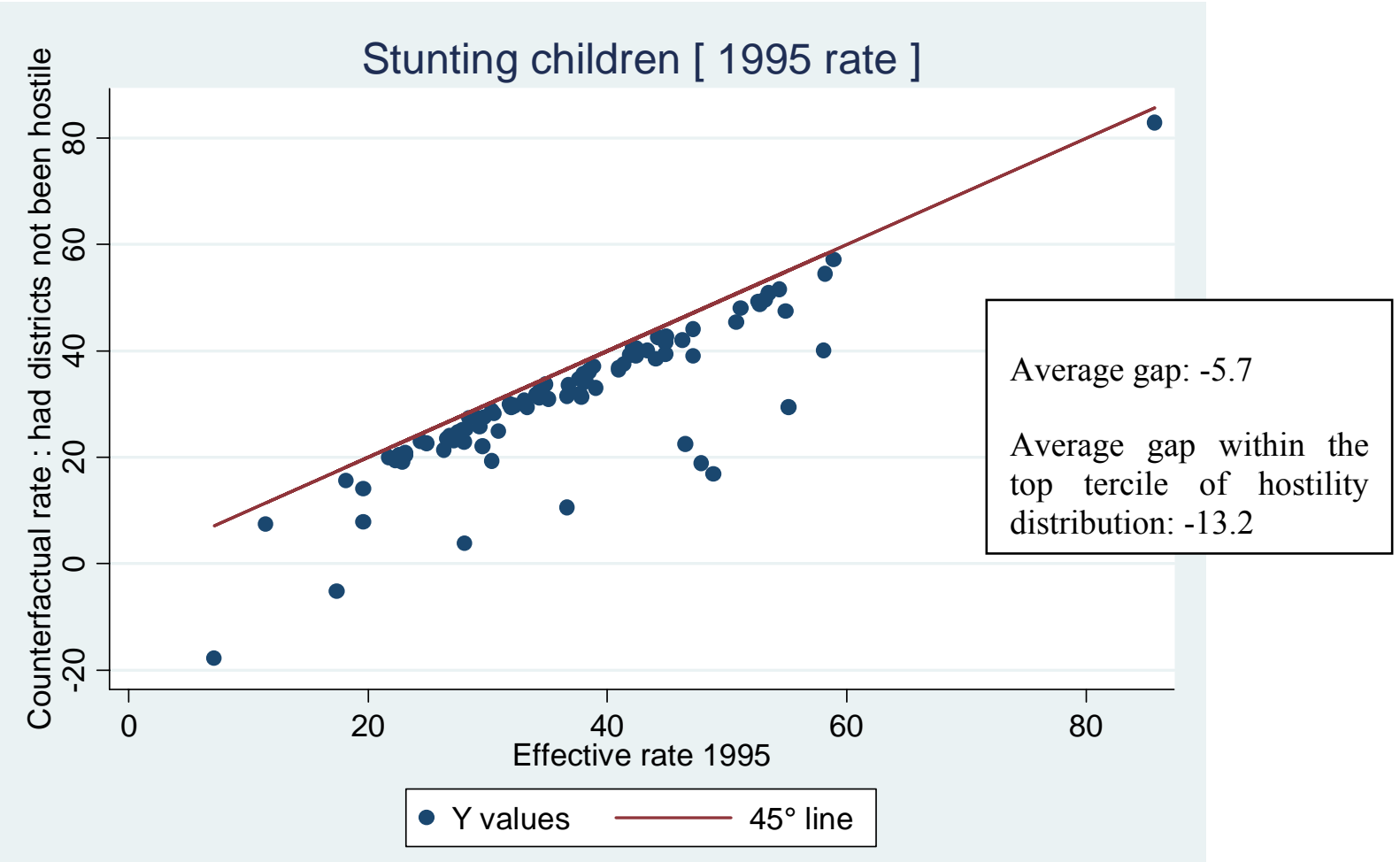




\section{Graph 13}

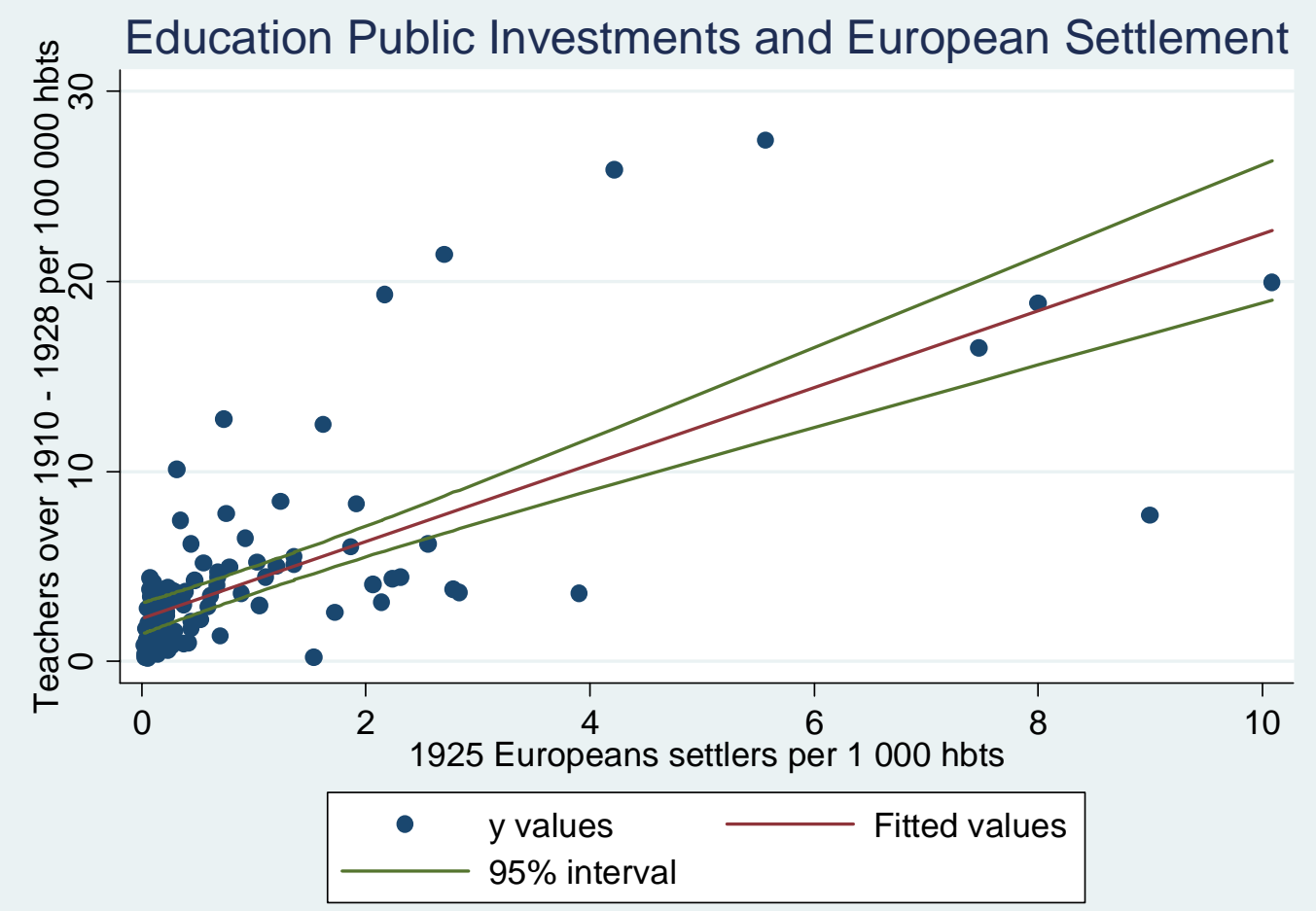

\section{Graph 14}

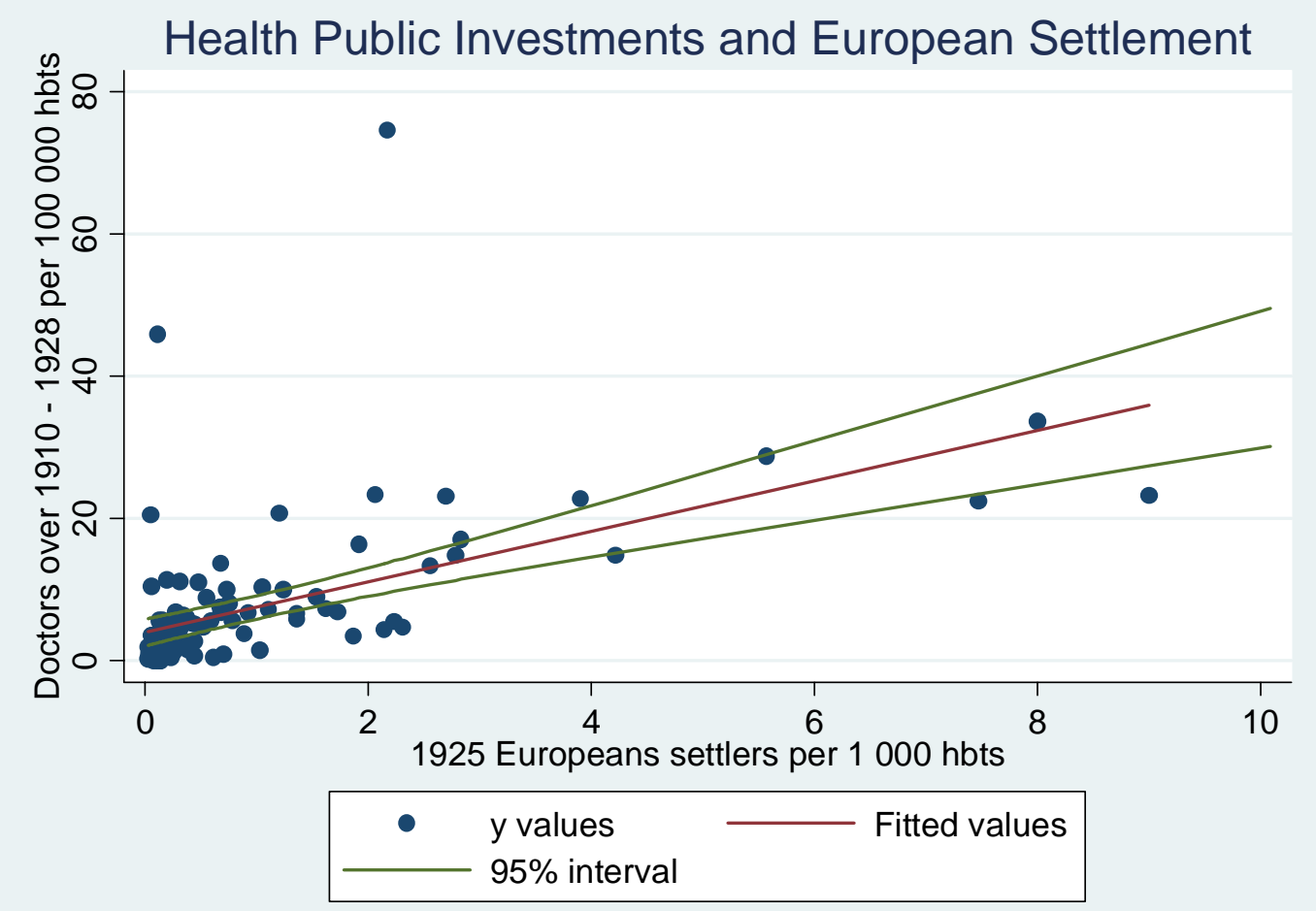




\section{Graph 15}

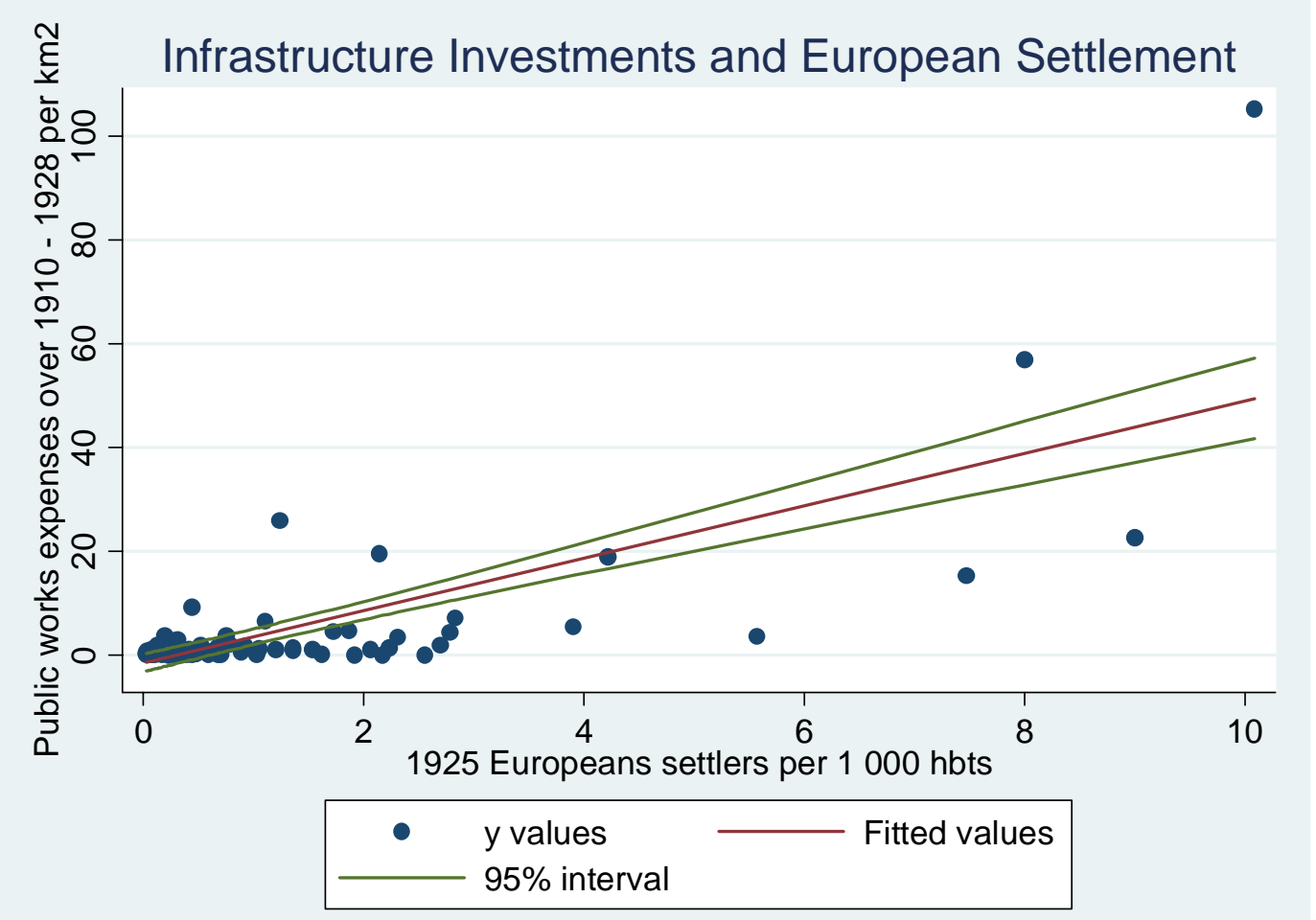


Appendix Table 1: The endogenous aspect of hostility

\begin{tabular}{|c|c|c|c|}
\hline \multirow[b]{2}{*}{ Independant variables } & \multicolumn{3}{|c|}{ Dependent variable } \\
\hline & Hostility H1 & Hostility $\mathrm{H} 2$ & Hostility H3 \\
\hline Population density in 1910 & $\begin{array}{l}\text { 0,0031* } \\
(0.0017)\end{array}$ & $\begin{array}{c}\mathbf{0 , 0 0 3 *} \\
(0.0017)\end{array}$ & $\begin{array}{c}\mathbf{0 , 0 1 *} \\
(0.006)\end{array}$ \\
\hline Desertic area dummy & $\begin{array}{c}0.26^{\star \star *} \\
(0.08)\end{array}$ & $\begin{array}{c}\mathbf{0 . 2 7} \\
(0.08)\end{array}$ & 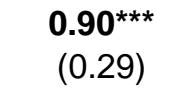 \\
\hline Trade counter dummy & $\begin{array}{l}-0.13 \\
(0.12)\end{array}$ & $\begin{array}{c}0.05 \\
(0.11)\end{array}$ & $\begin{array}{c}0.58 \\
(0.39)\end{array}$ \\
\hline Precolonial kingdom dummy & $\begin{array}{l}\mathbf{0 . 1 7} \\
(0.05)\end{array}$ & $\begin{array}{c}\mathbf{0 . 2 2} 2^{\star * *} \\
(0.05)\end{array}$ & $\begin{array}{c}\mathbf{0 . 4 2} \\
(0.16)\end{array}$ \\
\hline Acephalous area dummy & $\begin{array}{c}\mathbf{0 . 5 8} 8^{\star * *} \\
(0.08)\end{array}$ & $\begin{array}{c}\mathbf{0 . 5 3} 3^{* * *} \\
(0.08)\end{array}$ & $\begin{array}{l}1.60^{* * *} \\
(0.27)\end{array}$ \\
\hline Local chiefs wages (in million francs) & $\begin{array}{l}8.7^{\star \star *} \\
(3.27)\end{array}$ & $\begin{array}{l}9.7^{* * *} \\
(3.16)\end{array}$ & $\begin{array}{l}24.5^{\star *} \\
(10.9)\end{array}$ \\
\hline Altitude & $\begin{array}{l}-0.00 \\
(0.00)\end{array}$ & $\begin{array}{c}0.00 \\
(0.00)\end{array}$ & $\begin{array}{c}0.00 \\
(0.00)\end{array}$ \\
\hline Coastal dummy & $\begin{array}{l}0.16^{\star *} \\
(0.08)\end{array}$ & $\begin{array}{c}0.07 \\
(0.08)\end{array}$ & $\begin{array}{c}0.02 \\
(0.27)\end{array}$ \\
\hline River dummy & $\begin{array}{l}0.012 \\
(0.05)\end{array}$ & $\begin{array}{c}0.03 \\
(0.05)\end{array}$ & $\begin{array}{c}0.09 \\
(0.17)\end{array}$ \\
\hline Annual rainfalls & $\begin{array}{c}0.00 \\
(0.00)\end{array}$ & $\begin{array}{c}\text { 0.0001** } \\
(0.00006)\end{array}$ & $\begin{array}{l}\mathbf{0 . 0 0 0 4}^{\text {** }} \\
(0.0002)\end{array}$ \\
\hline Latitude & $\begin{array}{c}\mathbf{0 . 0 2 8}^{* *} \\
(0.13)\end{array}$ & $\begin{array}{c}\mathbf{0 . 0 3 7 * * *} \\
(0.13)\end{array}$ & 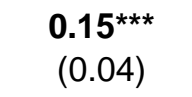 \\
\hline longitude & $\begin{array}{c}\mathbf{0 . 0 1 9 * * *} \\
(0.005)\end{array}$ & $\begin{array}{c}\mathbf{0 . 0 1 8}^{\text {****}} \\
(0.005)\end{array}$ & $\begin{array}{c}\mathbf{0 . 0 7} 7^{* * *} \\
(0.02)\end{array}$ \\
\hline $\mathrm{Nb}$ Obs & 110 & 110 & 110 \\
\hline R2 & 0.52 & 0.52 & 0.49 \\
\hline
\end{tabular}

*** significant at the $1 \%$ level, ** $5 \%$ level, * $10 \%$ level, $+15 \%$ level.

Each cell represents the coefficient from an OLS regression of the dependent variable on the independent variable.

Geographical controls are: average annual precipitations over 1910-1970, altitude, longitude, latitude, navigable river dummy and coast dummy.

$\mathrm{H} 1$ is the occurrence rate of events expressing hostility over 1906-1920

$\mathrm{H} 2$ is the occurrence rate of only severe events expressing hostility over 1906-1920

$\mathrm{H} 3$ is the average annual number of severe events expressing hostility over 1906-1920 


\section{Appendix Table 2: Using distance from the nearest seaport as an alternative instrument}

\begin{tabular}{|c|c|c|c|c|c|c|c|c|}
\hline \multirow[b]{2}{*}{ Independant variables } & \multicolumn{8}{|c|}{ Dependent variable: district performance rate (in percentage points) with respect to... } \\
\hline & $\begin{array}{c}(1) \\
\text { Literacy }\end{array}$ & $\begin{array}{c}(2) \\
\text { Primary } \\
\text { School } \\
\end{array}$ & $\begin{array}{c}\text { (3) } \\
\text { Second. } \\
\text { School }\end{array}$ & Water & $\begin{array}{c}\text { (5) } \\
\text { Electricity }\end{array}$ & $\begin{array}{c}(6) \\
\text { Modern } \\
\text { Combustible } \\
\end{array}$ & $\begin{array}{c}(7) \\
\text { Wall } \\
\text { Solidity }\end{array}$ & $\begin{array}{c}\text { (8) } \\
\text { Roof } \\
\text { Solidity } \\
\end{array}$ \\
\hline \multicolumn{9}{|c|}{ Panel A : IV Estimates using hostility $(H 3)$ as an instrument } \\
\hline Europeans per 1000 hbts in 1925 & $\begin{array}{l}\text { 0.56* } \\
(0.32)\end{array}$ & $\begin{array}{l}\mathbf{0 . 5 2} 2^{\star *} \\
(0.24)\end{array}$ & $\begin{array}{c}\mathbf{0 . 4 5} 5^{\star \star *} \\
(0.14)\end{array}$ & $\begin{array}{c}1.76^{* * *} \\
(0.34)\end{array}$ & $\begin{array}{c}1.31^{\text {*** }}(0.35)\end{array}$ & $\begin{array}{l}1.54^{\star *} \\
(0.79)\end{array}$ & $\begin{array}{l}1.19^{\star *} \\
(0.52)\end{array}$ & $\begin{array}{c}\mathbf{0 . 4 8}^{\star \star * *} \\
(0.17)\end{array}$ \\
\hline Partial R-squared & 0.33 & 0.33 & 0.33 & 0.33 & 0.33 & 0.33 & 0.33 & 0.33 \\
\hline Nb Obs & 109 & 109 & 109 & 109 & 109 & 109 & 109 & 109 \\
\hline
\end{tabular}

Included instruments

Population density 1910, Deser-edge dummy, Former trade counter dummy, Kingdom dummy,

Amorphous area dummy, Local chiefs wages, Average annual precipitations over 1915-1975,

Altitude, Latitude, Longitude, River dummy and Coast dummy.

Excluded instruments Hostility $(\mathrm{H} 3), \mathrm{H} 3^{\star}$ Population density $1910, \mathrm{H} 3^{\star}$ Desert-edge dummy, H3*Former trade counter dummy

Panel B : IV Estimates using distance from the nearest seaport as an intrument

Europeans per 1000 hbts in 1925

\begin{tabular}{|c|c|c|c|c|c|c|c|}
\hline $\begin{array}{c}4.92^{* * *} \\
(1.38)\end{array}$ & $\begin{array}{c}\mathbf{3 . 0 0} \text { *** } \\
(0.85)\end{array}$ & $\begin{array}{c}1.16^{* * *} \\
(0.29)\end{array}$ & $\begin{array}{c}2.99^{\star \star *} \\
(0.80)\end{array}$ & $\begin{array}{c}3.82^{* * *} \\
(0.89)\end{array}$ & $\begin{array}{c}10.06^{\star *} \\
(3.00)\end{array}$ & $\begin{array}{c}\text { 3.14 } \\
(1.11)\end{array}$ & $\begin{array}{c}1.99 * \star \star \\
(0.53)\end{array}$ \\
\hline 0.10 & 0.10 & 0.10 & 0.10 & 0.10 & 0.10 & 0.10 & 0.10 \\
\hline 109 & 109 & 109 & 109 & 109 & 109 & 109 & 109 \\
\hline
\end{tabular}

Partial R-squared

$\mathrm{Nb}$ Obs

Included instruments

Population density 1910, Deser-edge dummy, Former trade counter dummy, Kingdom dummy, Amorphous area dummy, Average annual precipitations over 1915-1975, Altitude, Latitude, Longitude and River dummy

Excluded instruments Distance from the nearest seaport

Panel B : IV Estimates using distance from the nearest seaport as an intrument within coastal districts only

\begin{tabular}{|c|c|c|c|c|c|c|c|c|}
\hline Europeans per 1000 hbts in 1925 & $\begin{array}{l}1.79 * * \\
(0.74)\end{array}$ & $\begin{array}{l}\mathbf{0 . 6 6 ^ { * }} \\
(0.38)\end{array}$ & $\begin{array}{l}\mathbf{0 . 7 3} \text { ** } \\
(0.33)\end{array}$ & $\begin{array}{c}\mathbf{1 . 9 2} \mathbf{2}^{\star \star \star *} \\
(0.72)\end{array}$ & $\begin{array}{c}\text { 3.36***} \\
(1.31)\end{array}$ & $\begin{array}{l}3.25^{*} \\
(1.76)\end{array}$ & $\begin{array}{l}\text { 2.98* } \\
(1.58)\end{array}$ & $\begin{array}{l}1.50^{* *} \\
(0.65)\end{array}$ \\
\hline Partial R-squared & 0.19 & 0.19 & 0.19 & 0.19 & 0.19 & 0.19 & 0.19 & 0.19 \\
\hline $\mathrm{Nb}$ Obs & 21 & 21 & 21 & 21 & 21 & 21 & 21 & 21 \\
\hline
\end{tabular}

Included instruments Population density 1910, Deser-edge dummy, Former trade counter dummy, Kingdom dummy, Amorphous area dummy, Latitude

Excluded instruments Distance from the nearest seapor

\section{E** significant at the $1 \%$ level, $* \star 5 \%$ level, ${ }^{*} 10 \%$ level.}

Each cell represents the coefficient from a 2 SLS regression of the dependent variable on the independent variable.

Instrumented variable is the number of Europeans per 1,000 inhabitants in 1925

In panel $C$, the sample include coastal districts only. 